\title{
Xentry-Gap19 inhibits Connexin43 hemichannel opening especially during hypoxic injury
}

\author{
Frazer P. Coutinho ${ }^{1,2}$. Colin R. Green ${ }^{2}$ - Monica L. Acosta ${ }^{3} \cdot$ Ilva D. Rupenthal ${ }^{1,2}$
}

Published online: 21 April 2020

(C) Controlled Release Society 2020

\begin{abstract}
Hypoxic injury results in cell death, tissue damage and activation of inflammatory pathways. This is mediated by pathological Connexin43 (Cx43) hemichannel (HC) opening resulting in osmotic and ionic imbalances as well as cytokine production perpetuating the inflammatory environment. Gap19 is an intracellularly acting Cx43 mimetic peptide that blocks HC opening and thus promotes cell survival. However, native Gap19, which must enter the cell in order to function, exhibits low cell permeability. In this study, Gap19 was conjugated to the cell-penetrating peptide, Xentry, to investigate if cellular uptake could be improved while maintaining peptide function. Cellular uptake of Xentry-Gap19 (XG19) was much greater than that of native Gap19 even under normal cell culture conditions. Peptide function was maintained post uptake as shown by reduced ethidium homodimer influx and ATP release due to Cx43 HC block. While XG19 blocked pathologic HC opening though, normal gap junction communication required for cell repair and survival mechanisms was not affected as shown in a dye scrape-load assay. Under hypoxic conditions, increased expression of Syndecan-4, a plasma membrane proteoglycan targeted by Xentry, enabled even greater XG19 uptake leading to higher inhibition of ATP release and greater cell survival. This suggests that XG19, which is targeted specifically to hypoxic cells, can efficiently and safely block $\mathrm{Cx} 43 \mathrm{HC}$ and could therefore be a novel treatment for hypoxic and inflammatory diseases.
\end{abstract}

Keywords Cell-penetrating peptide $\cdot$ Connexin $43 \cdot$ Hemichannel $\cdot$ Mimetic peptide $\cdot$ Syndecan-4 $\cdot$ Hypoxia $\cdot$ Xentry $\cdot$ Gap 19

\section{Introduction}

Hypoxia is a major detrimental factor in ischaemic diseases such as stroke and vascular eye conditions, where the blood flow to tissues and organs is reduced resulting in limited oxygen supply [1]. The events occurring during hypoxia are worsened by sudden reperfusion which is referred to as ischaemia-reperfusion injury [2]. Hypoxia is often associated with the production of pro-inflammatory cytokines as well as

Ilva D. Rupenthal

i.rupenthal@auckland.ac.nz

1 Buchanan Ocular Therapeutics Unit, Department of Ophthalmology, New Zealand National Eye Centre, University of Auckland, Auckland, New Zealand

2 Department of Ophthalmology, New Zealand National Eye Centre, University of Auckland, Auckland, New Zealand

3 School of Optometry and Vision Science, New Zealand National Eye Centre, University of Auckland, Auckland, New Zealand the overexpression of proteins such as vascular endothelial growth factor (VEGF), Connexin43 (Cx43) and Syndecan-4 [2-8]. In neovascular age-related macular degeneration (nAMD), for example, unregulated growth of poorly formed blood vessels, known as choroidal neovascularization, results in haemorrhage within the retina leading to tissue ischaemia $[9,10]$. To compensate for the disruption in blood/oxygen supply, VEGF is overexpressed by the retinal pigment epithelium (RPE), which contributes to the blood-retinal barrier (BRB) between the vascular choroid and the neural retina $[11,12]$. This VEGF overexpression perpetuates the formation of leaky blood vessels $[11,12]$, which introduces more inflammatory factors to the environment, increases Cx43 expression and causes RPE cell death due to hypoxia, ultimately permitting blood vessel growth into the retina and leading to vision loss.

Cx43 hemichannel (HC) blockers have been shown to prevent vessel leak, support repair of leaky blood vessels and promote tissue repair in numerous animal models $[2,13$, 14]. Cx43 is responsible for the formation of gap junctions $[15,16]$, which mediate communication between cells by 
permitting the passage of small molecules for homeostatic processes such as growth, repair and survival. Six connexin monomers form a $\mathrm{HC}$ which undocked under normal conditions is closed, while docking of two $\mathrm{HC}$ from neighbouring cells results in the formation of a gap junction which opens during physiologic conditions to allow exchange of cellular contents [16-18]. During pathology, however, normally closed, undocked $\mathrm{HC}$ are stimulated to open to the extracellular environment eventually resulting in cell death [19-23]. Sudden tissue reperfusion during open $\mathrm{Cx} 43 \mathrm{HC}$ states drastically increases cell death and tissue damage as cells are unable to cope with the rapid ionic influx. In chronic hypoxic or inflammatory conditions, $\mathrm{Cx} 43 \mathrm{HC}$ have been referred to as "pathologic pores" as they are responsible for the activation of the inflammatory cascade via the nod-like receptor family pyrin domain containing 3 (NLRP3) inflammasome complex leading to the production of inflammatory cytokines and thus perpetuating the inflammatory environment $[14,24-26]$. Blocking open $\mathrm{Cx} 43 \mathrm{HC}$ during injury using $\mathrm{Cx} 43$ mimetic peptides such as Gap27 and Pepide5 has been shown to promote cell survival and tissue repair in cardiac, spinal cord injury and ocular models $[27,28]$. However, one concern with these peptides is their action on external motifs of $\mathrm{Cx} 43$, potentially affecting gap junction function required for cell survival when used at high concentrations and/or long exposure periods [29-31].

Gap19 is a HC blocker derived from the second cytoplasmic loop of $\mathrm{Cx} 43$ which does not interfere with gap junction function. However, it requires entering the cell in order to bind to the corresponding sequence of the cytoplasmic tail of $\mathrm{Cx} 43$ [32]. Due to its poor cell penetration, high concentrations have previously been used but with limited efficacy [32, 33]. Cellpenetrating peptides (CPP) are an efficient way of transporting cargo molecules across the cell membrane. The CPP Xentry is derived from the $\mathrm{X}$-protein of the hepatitis $\mathrm{B}$ virus and has been shown to efficiently transport a range of molecules into cells via endocytic mechanisms by binding to cell surfaceexpressed Syndecan-4 [34]. As Syndecan-4 is not expressed on circulating monocytes and erythrocytes, sequestration by the circulation, if delivered systemically, is prevented [34], while uptake into Syndecan-4 overexpressing cells is increased. This study investigated whether conjugation of Xentry to Gap19 (XG19) can increase the cellular uptake of Gap19 to efficiently block Cx43 HC-mediated injury in hypoxic cells at low peptide concentrations.

\section{Materials and methods}

\section{Materials}

Xentry-Gap19 (XG19) (1clrpvGGKQIEIKKFK), Gap19 (KQIEIKKFK) and FITC-labelled peptides at 95\% purity were obtained from ChinaPeptide Co., Ltd. Peptide5 (VDCFLSRPTEKT) was purchased from Auspep. Dulbecco's Modified Eagle Medium/Nutrient Mixture F-12 (DMEM/F-12; GlutaMAX ${ }^{\mathrm{TM}}$ medium), EGM-2 ${ }^{\mathrm{TM}}$ BulletKit ${ }^{\mathrm{TM}}$ medium, foetal bovine serum, antibioticantimycotic (AA), ethidium homodimer-1 (EthD-1), 3-(4,5dimethylthiazol-2-yl)-2,5-diphenyltetrazolium bromide (MTT) and Lucifer Yellow were purchased from Thermo Fisher Scientific. Carbenoxolone (CBX), 4',6-diamidino-2phenylindole (DAPI) and formaldehyde were obtained from Sigma-Aldrich. Constituents of high calcium solution/Hank's balanced salt solution (HBSS) $(0.137 \mathrm{M} \mathrm{NaCl}, 5.4 \mathrm{mM} \mathrm{KCl}$, $0.25 \mathrm{mM} \mathrm{Na}_{2} \mathrm{HPO}_{4}, 5.6 \mathrm{mM}$ glucose, $0.44 \mathrm{mM} \mathrm{KH}_{2} \mathrm{PO}_{4}$, $1.3 \mathrm{mM} \mathrm{CaCl}_{2}, 1.0 \mathrm{mM} \mathrm{MgSO}_{4}$ and $4.2 \mathrm{mM} \mathrm{NaHCO}_{3}$ in $100 \mathrm{ml}$ of ultrapure water); low calcium solution $(0.137 \mathrm{M}$ $\mathrm{NaCl}, 5.4 \mathrm{mM} \mathrm{KCl}, 0.25 \mathrm{mM} \mathrm{Na}_{2} \mathrm{HPO}_{4}, 5.6 \mathrm{mM}$ glucose, $0.44 \mathrm{mM} \mathrm{KH}_{2} \mathrm{PO}_{4}, 1.0 \mathrm{mM} \mathrm{MgSO}_{4}, 4.2 \mathrm{mM} \mathrm{NaHCO}_{3}$ and $5 \mathrm{mM}$ EGTA in $100 \mathrm{ml}$ of ultrapure water); and hypoxic, acidic, ion-shifted Ringer (HAIR) solution $(38 \mathrm{mM} \mathrm{NaCl}$, $13 \mathrm{mM} \mathrm{NaHCO}_{3}, 3 \mathrm{mM} \mathrm{Na}$-gluconate, $65 \mathrm{mM} \mathrm{K}$-gluconate, $38 \mathrm{mM} \mathrm{N}$-methyl-D-glucamine, $1 \mathrm{mM} \mathrm{NaH}_{2} \mathrm{PO}_{4}$ and $1.5 \mathrm{mM}$ $\mathrm{MgCl}_{2}$ in $100 \mathrm{ml}$ of ultrapure water) $[35,36]$ were of analytical grade. Immortalized human retinal pigment epithelium cells (ARPE-19) were purchased from American Type Culture Collection (ATCC), while primary human retinal microvascular endothelial cells (hRMEC) were obtained from Neuromics.

\section{Cell seeding and imaging}

ARPE-19 or hRMEC were harvested with TrypLETM, centrifuged at $1500 \mathrm{rpm}$ for $7 \mathrm{~min}$, resuspended in culture medium (for ARPE-19 cells: DMEM/F-12, GlutaMAX ${ }^{\mathrm{TM}}$ medium with $10 \% \mathrm{FBS}$ and $1 \% \mathrm{AA}$; for hRMEC: EGM-2 BulletKit ${ }^{\mathrm{TM}}$ medium containing endothelial basal medium (EBM-2 and EGM-2 SingleQuots ${ }^{\mathrm{TM}}$ (excluding VEGF) with $10 \%$ FBS and $1 \% \mathrm{AA}$ ) and counted using trypan blue and the Neubauer haemocytometer. Cells were plated into appropriate culture dishes (8-well chamber slides, 6-, 12-, 24- or 96-well plates) at a seeding density of $2 \times 10^{5}$ cells/ $/ \mathrm{ml}$ and were incubated with the relevant culture medium over two nights at $37{ }^{\circ} \mathrm{C}$ with $5 \% \mathrm{CO}_{2}$ before conducting the various assays. Images were acquired using an Olympus BX-10 microscope with a FV-1000 confocal laser scanning system and Olympus FV-10 software with area measurements performed using ImageJ. Statistical analysis was carried out using GraphPad Prism 7 software with the test used stated in each figure caption.

\section{Cellular uptake}

FITC-labelled Gap19 and XG19 were dissolved in culture medium and applied to ARPE-19 or hRMEC in 8-well 
chamber slides at $5,10,20,50$ and $100 \mu \mathrm{M}$ for $1 \mathrm{~h}$ at $37^{\circ} \mathrm{C}$ with $5 \% \mathrm{CO}_{2}$. For cell uptake under hypoxic conditions, peptides were mixed with HAIR solution at 5, 10 and $20 \mu \mathrm{M}$ instead of normal culture medium. After $1 \mathrm{~h}$, the medium was removed for both normal and hypoxic uptake assays, cells were washed with PBS and fixed in 4\% formaldehyde in PBS and nuclei were counterstained with DAPI (diluted 1:1000 in $1 \%$ PBS). Coverslips were mounted in anti-fade medium (Citifluor ${ }^{\mathrm{TM}} \mathrm{AF} 1$ ), and cells were visualized using a confocal microscope.

\section{Syndecan-4 and Cx43 labelling}

Medium was replaced with either fresh cell culture medium or HAIR solution, and cells were incubated for 1, 3, 6 or $24 \mathrm{~h}$ at $37{ }^{\circ} \mathrm{C}$ with $5 \% \mathrm{CO}_{2}$. Cells were then washed with PBS and fixed in $4 \%$ formaldehyde/PBS at room temperature for 10 min. Cells were again washed with PBS and labelled with primary antibody (anti-Syndecan-4 raised in goat (1:5; RDSAF2918; R\&D systems) or anti-Cx43 raised in rabbit (1:2000; C6219; Sigma-Aldrich) in PBS overnight. The next day, excess primary antibody was washed away with PBS before applying the secondary antibody (anti-goat 488 raised in donkey (1:100; ab150155; Abcam) or anti-rabbit 488 raised in goat (1:500; A11034, Thermo Fisher Scientific)) and DAPI (1:1000) in PBS for $1 \mathrm{~h}$ at room temperature in a humid box. Coverslips were mounted in anti-fade medium (Citifluor ${ }^{\mathrm{TM}}$ AF1), and cells were visualized using confocal microscopy.

\section{Cell viability post XG19 uptake}

XG19 was mixed with culture medium or HAIR solution and applied to ARPE-19 cells seeded into 96-well plates at 5, 10 or $20 \mu \mathrm{M}$ for either 1 or $24 \mathrm{~h}$ at $37{ }^{\circ} \mathrm{C}$ with $5 \% \mathrm{CO}_{2}$. After the incubation period, solutions in each well were replaced with $0.5 \mathrm{mg} / \mathrm{ml}$ of MTT in PBS and incubated for $4 \mathrm{~h}$ at $37^{\circ} \mathrm{C}$ with $5 \% \mathrm{CO}_{2}$. The MTT/PBS solution was then replaced with hydrochloride-isopropanol solution $(0.04 \mathrm{M})$ to dissolve the formed formazan. The intensity of the purple colour was quantified at $570 \mathrm{~nm}$ with correction of interference at $650 \mathrm{~nm}$ (BioTek Synergy HT). Each group was tested in triplicate (three wells of a 96-well plate) on two separate occasions.

\section{EthD-1 uptake}

XG19 $(5 \mu \mathrm{M})$ or FITC-XG19 $(5 \mu \mathrm{M})$ mixed with culture medium was applied to ARPE-19 cells seeded into 8-well chamber slides and incubated for $1 \mathrm{~h}$ at $37{ }^{\circ} \mathrm{C}$ with $5 \% \mathrm{CO}_{2}$. High $\left(1.3 \mathrm{mM} \mathrm{Ca}^{2+}\right.$, closes $\left.\mathrm{Cx} 43 \mathrm{HC}\right)$ or low calcium $(0 \mathrm{mM}$ $\mathrm{Ca}^{2+}$, opens $\mathrm{Cx} 43 \mathrm{HC}$ and allows dye uptake) solution containing $2 \mu \mathrm{M}$ of EthD-1 fluorescent dye was applied to cells for $40 \mathrm{~min}$. Solutions were removed, cells were washed in
PBS and fixed in 4\% formaldehyde in PBS and nuclei were counterstained with DAPI. Coverslips were mounted in antifade medium (Citifluor ${ }^{\mathrm{TM}} \mathrm{AF} 1$ ), and cells were visualized using a confocal microscope.

\section{ATP release}

XG19 $(5,10,20 \mu \mathrm{M})$, Peptide $5(20 \mu \mathrm{M})$ or CBX $(100 \mu \mathrm{M})$ were mixed with either culture medium or HAIR solution and applied to ARPE-19 cells seeded in 12-well plates for 0,1 or $24 \mathrm{~h}$ at $37{ }^{\circ} \mathrm{C}$ with $5 \% \mathrm{CO}_{2}$. The medium was then removed, and low calcium solution was applied to the cells for $35 \mathrm{~min}$ at $37{ }^{\circ} \mathrm{C}$ with $5 \% \mathrm{CO}_{2}$. Solutions were removed and transferred into a black 96-well plate, and ATP measurements were performed as per the instructions of the ATPlite kit (no. 6016943; Perkin Elmer) using a Victor X Light luminescence plate reader.

\section{Dye scrape-load gap junction assay}

XG19 and CBX were mixed with culture medium and applied to ARPE-19 cells seeded in 8-well plates at 5 and $100 \mu \mathrm{M}$ for $1 \mathrm{~h}$ at $37^{\circ} \mathrm{C}$ with $5 \% \mathrm{CO}_{2}$. Solutions were removed, and cells were exposed to $0.1 \%$ Lucifer Yellow in high calcium solution for $15 \mathrm{~min}$ at room temperature after a horizontal scrape was created in the cell monolayer using a pipette tip. The Lucifer Yellow solution was removed, cells were washed in PBS and fixed in 4\% formaldehyde in PBS and nuclei were counterstained with DAPI. Coverslips were mounted in anti-fade medium (Citifluor ${ }^{\mathrm{TM}} \mathrm{AF} 1$ ), and cells were visualized by a confocal microscope. To quantify dye transfer using Image J, image measurement scales were set to pixels and areas of Lucifer Yellow dye spread were selected using the colour threshold feature to separate fluorescent from non-fluorescent cells and background. Statistical analysis was carried out using Prism GraphPad software.

\section{Results and discussion}

\section{Cellular uptake}

In nAMD, choroidal endothelial cell damage results in vascular permeability and loss of BRB integrity due to RPE cell death $[37,38]$. Primary hRMEC and immortalized ARPE-19 cultures present similar physiological characteristics to the inner and outer BRB, respectively [39-41], while also expressing functional $\mathrm{Cx} 43 \mathrm{HC}$. They are thus ideal to assess the efficacy of $\mathrm{Cx} 43 \mathrm{HC}$ blockers $[25,42]$ as a potential treatment for nAMD or similar indications. Cx43 HC inhibition has been shown to reduce vascular permeability, inflammation and cell death in numerous ocular disease models $[2,13,25$, $36,42-45]$. However, in order to block Cx43 HC opening, 
Gap19 must enter the cell and gain access to the cytoplasmic tail of $\mathrm{Cx} 43$ to inhibit intracellular loop-tail interactions [46]. Since native Gap19 has limited cell permeability, we investigated the uptake of Xentry-conjugate Gap19 (XG19) in comparison with the native peptide (both tagged to FITC) in hRMEC and ARPE-19 cells (Fig. 1a, b, respectively).

As can be seen, XG19 uptake occurred in a dose-dependant manner as observed by increasing FITC fluorescence with increasing XG19 concentrations in both hRMEC and ARPE-19 cells (Fig. 1a, b, respectively). Using native Gap 19 , no fluorescence was visible at concentrations below $50 \mu \mathrm{M}$ in hRMEC and $100 \mu \mathrm{M}$ in ARPE-19 cells suggesting that the native form was unable to enter the cells at low concentrations. The amount of uptake observed at 10 and $20 \mu \mathrm{M}$ of XG19 was far greater than that of Gap19 at $100 \mu \mathrm{M}$ in either cell culture, confirming that the addition of the CPP, Xentry, to Gap19 improved peptide cellular uptake even under normal culture conditions.

Previous attempts to observe in vitro function of native Gap19 have necessitated high peptide concentrations with a half maximal $\mathrm{Cx} 43 \mathrm{HC}$ blocking effect seen at $142 \mu \mathrm{M}$ in astrocytes compared with $47 \mu \mathrm{M}$ in C6 (glioma) cells [32, 46]. Native Gap19 itself has some cell penetration ability due the four charged lysine residues in its sequence but seemed to better enter C6 cells compared with astrocytes. In a similar manner, native Gap19 was able to enter hRMEC marginally better than ARPE-19 cells. This could be due to the greater surface area available in hRMEC cultures compared with ARPE-19 cells which form tight junctions thus only allowing Gap19 to enter the cell from the apical surface [47]. The addition of Xentry vastly improved the uptake of Gap19 into both cell cultures with XG19 visually detectable from concentrations between 10 and $20 \mu \mathrm{M}$ and saturation of cells achieved at $50 \mu \mathrm{M}$. Uptake seemed to be more readily achieved in ARPE-19 compared with that in hRMEC which could be related to the amount of surface-expressed Syndecan-4 present in RPE compared with endothelial cells $[34,48,49]$. Since hRMEC and ARPE-19 cells are representative of in vivo retinal cells, the improved uptake seen here suggests that XG19 would be readily taken up by RPE as well as endothelial cells of the retina, which also share similar morphological characteristics with the choroidal vasculature [50].

Since XG19 cell entry is Syndecan-4 mediated [34] and Syndecan-4 is said to be upregulated in response to hypoxia by activation of HIF- $1 \propto[7,8]$, we subsequently investigated XG19 and Gap19 uptake in hypoxic compared with normal ARPE-19 cells (Fig. 2). While Gap19 was undetectable inside cells using both culturing conditions, XG19 uptake into hypoxic cells was much greater than in normal culture. Overall, higher uptake of XG19 by hypoxic ARPE-19 cells increases the potential for XG19 as a candidate therapeutic for nAMD as hypoxic RPE cells in vivo are likely to have higher
Syndecan-4 levels, therefore leading to preferential XG19 uptake by diseased cells $[1,8,34,49]$.

\section{Syndecan-4 and Cx43 labelling}

Since it was noticed that XG19 entered ARPE-19 cells more readily than hRMEC, cell cultures were labelled for Syndecan-4 to determine if the difference in expression under normal conditions was responsible for the variations in XG19 uptake observed [34]. ARPE-19 cells and hRMEC also express $\mathrm{Cx} 43$ and have been used to assess $\mathrm{Cx} 43 \mathrm{HC}$ opening as well as block with $\mathrm{Cx} 43$ mimetic peptides in vitro $[25,42]$. Thus, $\mathrm{Cx} 43$ levels were also investigated to determine which cell line would be preferable for $\mathrm{Cx} 43 \mathrm{HC}$ functional assays. As shown in Fig. 3, hRMEC and ARPE-19 both expressed Cx43 consistent with previous literature $[42,45,51]$ although expression was much greater in ARPE-19 cells. RPE cells naturally form a monolayer in vivo to create the outer BRB between the neural retina and the choroidal vasculature [52, 53]. As a result, ARPE-19 cells also form a more regular monolayer in culture with clearly defined cell boundaries $[40,54]$. These boundaries may account for the higher Cx 43 gap junction labelling while the homogeneity of the cell structure also renders them more suitable for functional assays.

While Syndecan-4 expression has previously been reported in primary human umbilical endothelial cells, this is the first investigation of Syndecan-4 expression in hRMEC [48]. Syndecan-4 expression was also observed in ARPE-19 cells, consistent with previous literature, and was shown to be higher than in hRMEC [49]. Syndecan-4 plays a diverse role in cell adhesion as well as intracellular and extracellular signalling $[55,56]$. In endothelial cells, Syndecan-4 is primarily required for the formation of focal adhesion and endothelial cell alignment to preserve the structure of blood vessels [48, 57]. RPE cells, on the other hand, interact with a number of extracellular molecules such as VEGF, fibroblast growth factor and platelet-derived growth factor to maintain homeostasis of the outer retina $[52,58,59]$. In the RPE, Syndecan- 4 can be utilized for cell adhesion by binding fibronectin for the formation of focal adhesions as well as binding of extracellular molecules in order to mediate signalling mechanisms to maintain retinal homeostasis $[49,56,60]$. The diverse function of Syndecan-4 in RPE cells is likely the reason for the higher Syndecan-4 labelling in ARPE-19 cells compared with hRMEC. Overall, being an immortalized cell line that allows for more reliable culturing and with the increased expression of Syndecan-4 and Cx43, ARPE-19 cells were preferred for further uptake and functional studies.

In a second step, Syndecan-4 expression in response to hypoxic injury was assessed over time. In nAMD, RPE cells are exposed to inflammatory cytokines such as TNF- $\alpha$ and IL1- $\beta[25,61,62]$. Furthermore, vascular permeability results in insufficient perfusion resulting in localized sites of 
a

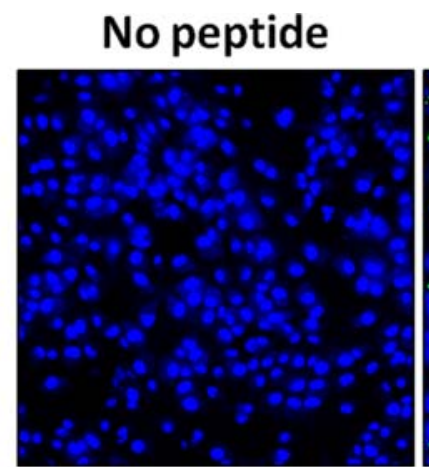

\section{$10 \mu \mathrm{M}$ Gap19}

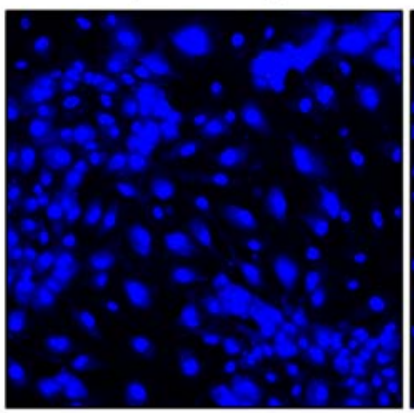

b

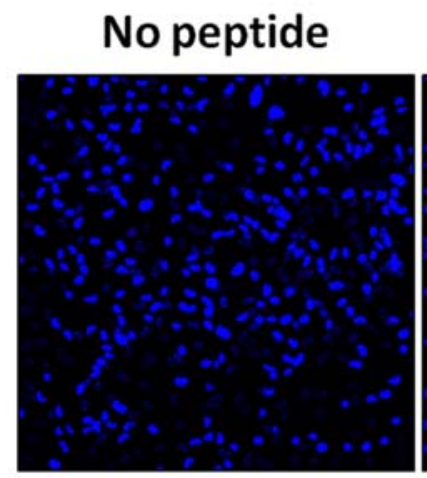

\section{$10 \mu \mathrm{M}$ Gap19}

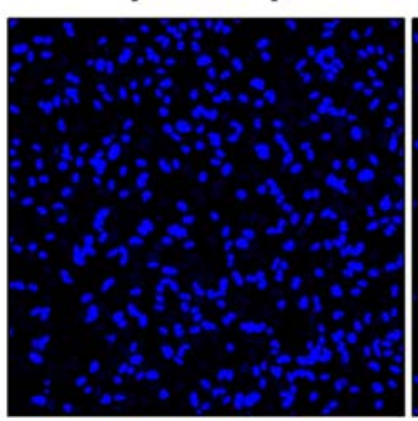

Fig. 1 XG19 and Gap19 uptake into hRMEC and ARPE-19 cells under normal conditions. hRMEC (a) and ARPE-19 cells (b) were either left untreated or were treated with XG19 $(10,20$ or $50 \mu \mathrm{M})$ or Gap19 $(10,20$,

ischaemia and hypoxia [2, 43]. Both inflammation and hypoxia are known to alter Syndecan-4 expression [8, 48, 63, 64]. In vitro, hypoxia can be induced by the application of HAIR
$20 \mu \mathrm{M} \times \mathrm{G} 19$

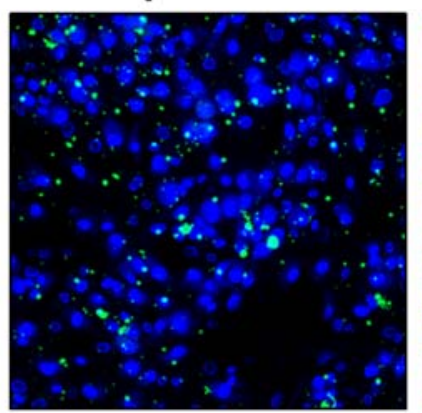

\section{$50 \mu \mathrm{M}$ Gap19}

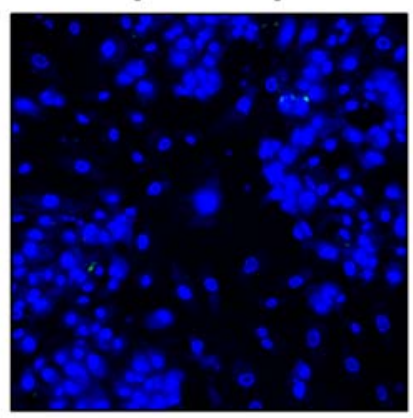

$100 \mu \mathrm{M}$ Gap19

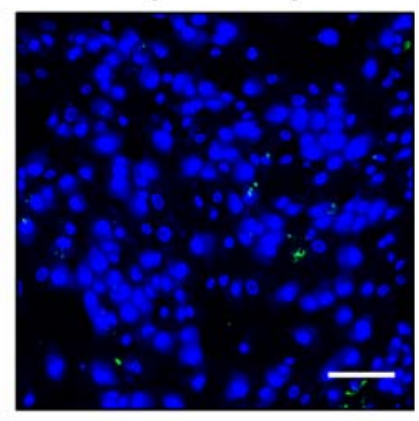

$20 \mu \mathrm{M}$ XG19

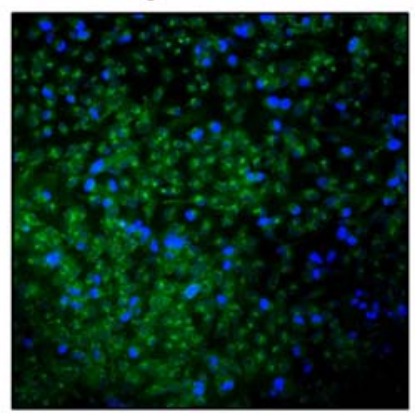

\section{$50 \mu \mathrm{M}$ Gap19}

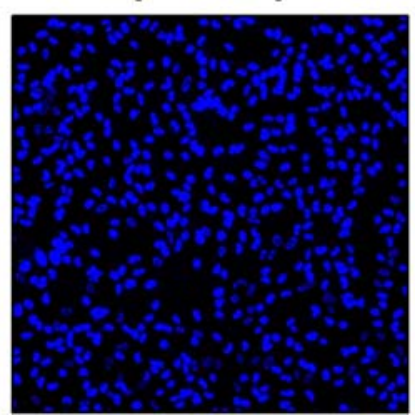

\section{$100 \mu \mathrm{M}$ Gap19}

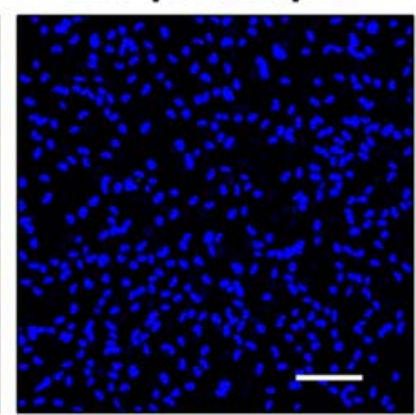

50 or $100 \mu \mathrm{M}$ ). Peptides were labelled with FITC (green) and nuclei were stained with DAPI (blue). Scale bar, $100 \mu \mathrm{m}$

solution which in addition to changes in Syndecan-4 expression also results in higher $\mathrm{Cx} 43$ levels as well as increased Cx43 HC opening [35, 36, 42]. As can be seen in Fig. 4a, 

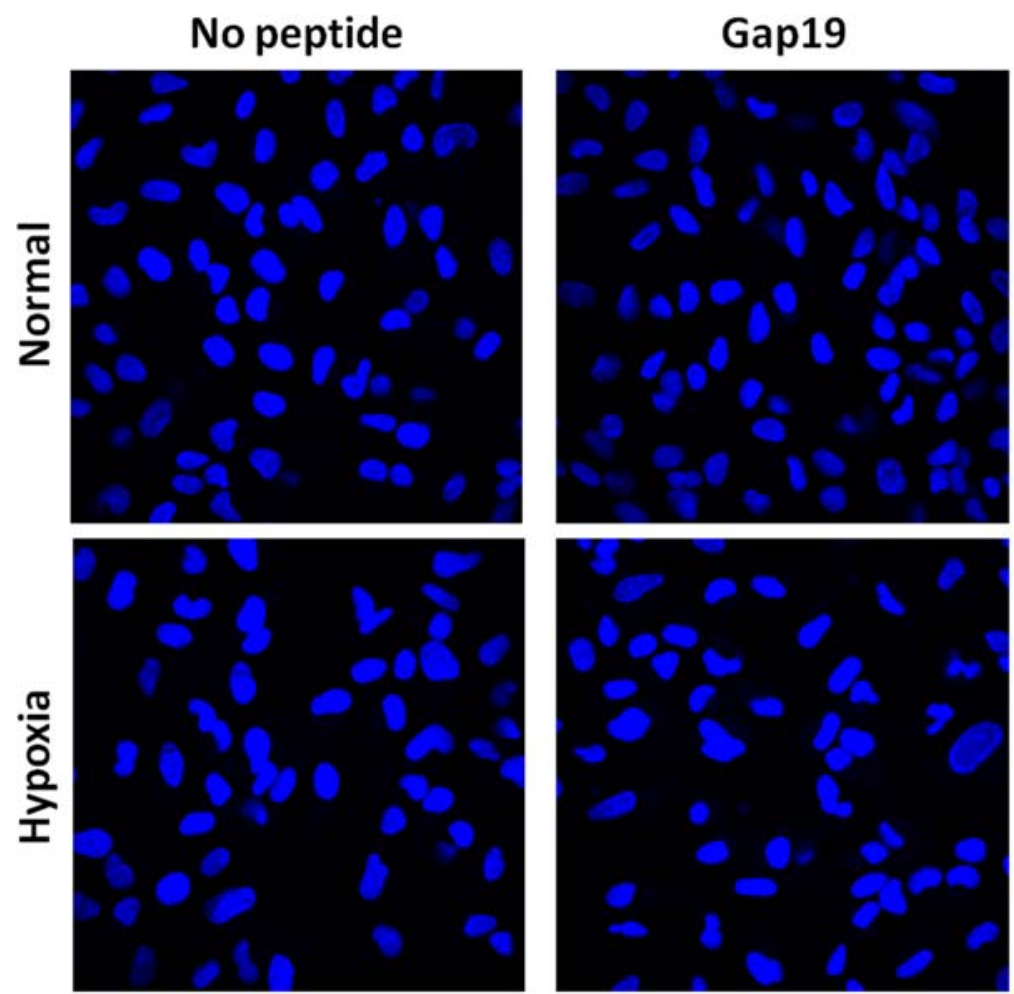

were also left untreated or treated with $100 \mu \mathrm{M}$ Gap 19 or $5 \mu \mathrm{M}$ XG19. Peptides were visualized by a FITC-tag (green), and cell nuclei were stained with DAPI (blue). Scale bar, $50 \mu \mathrm{m}$
Fig. 2 Uptake of Gap19 and XG19 in normal vs. hypoxic ARPE-19 cells. Normal cells were left untreated or were treated with $100 \mu \mathrm{M}$ Gap 19 or $5 \mu \mathrm{M}$ XG19. Cells exposed to HAIR solution in order to induce hypoxia
XG19
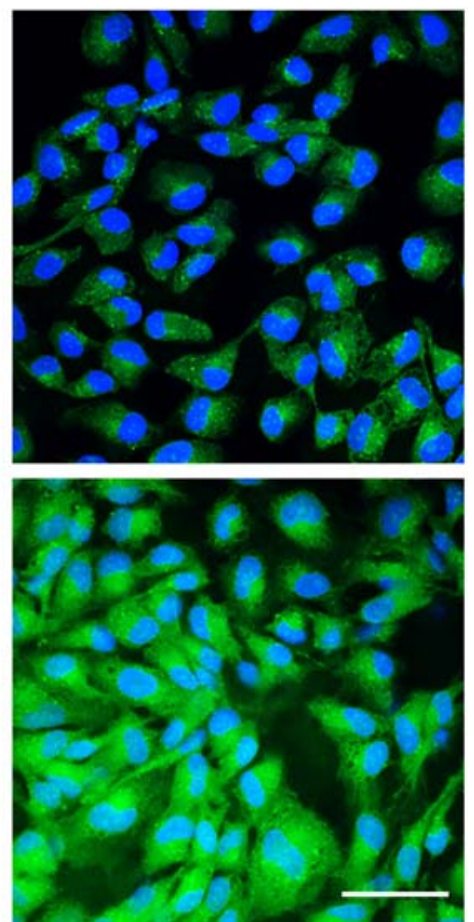

\section{Syndecan-4}
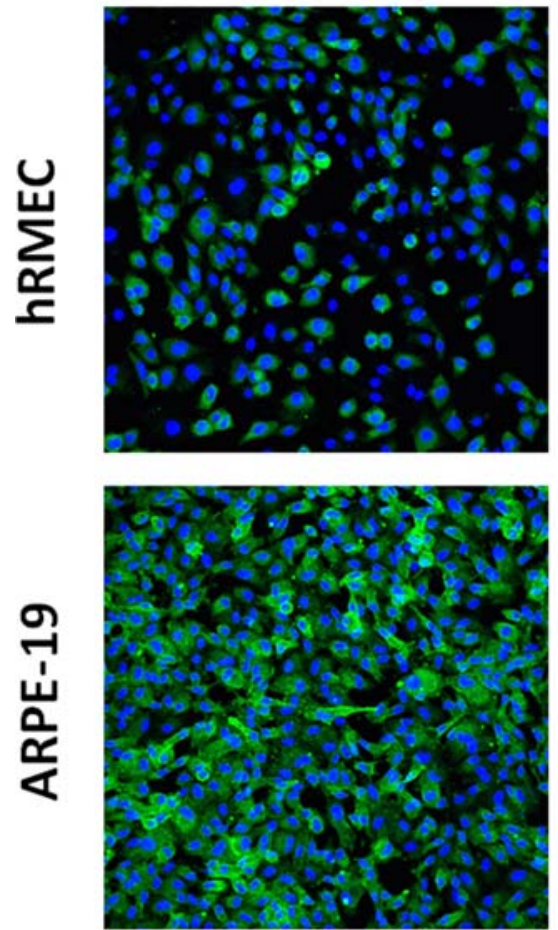

Fig. 3 Syndecan-4 and CX43 labelling as well as XG19 uptake under normal conditions. hRMEC and ARPE-19 cells were labelled for Syndecan-4, as well as $\mathrm{Cx} 43$, and were also treated with $50 \mu \mathrm{M}$ XG19.

\section{Cx43}
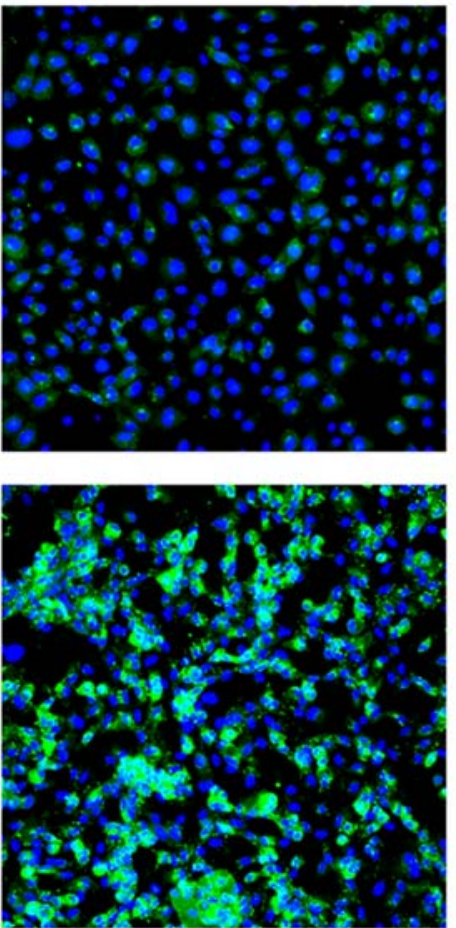

XG19
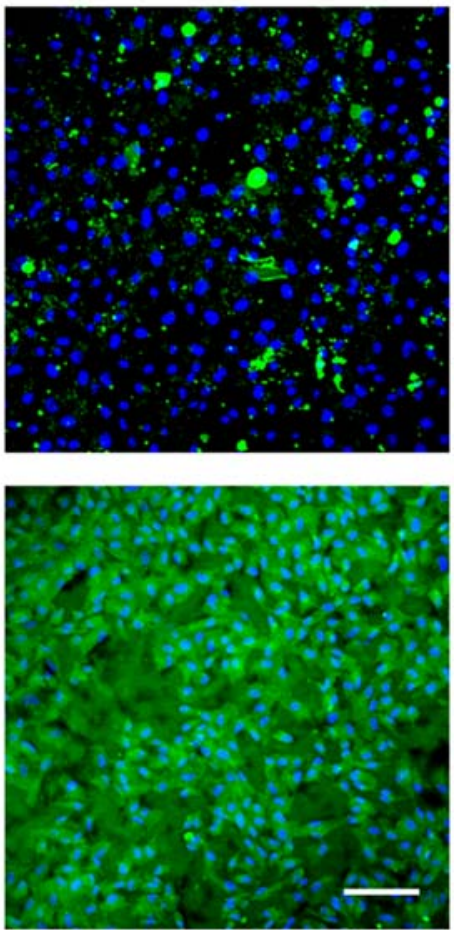

Syndecan-4, Cx43 and XG19 were labelled in green while nuclei were stained with DAPI (blue). Scale bar, $100 \mu \mathrm{m}$ 
a $1 \mathrm{~h}$
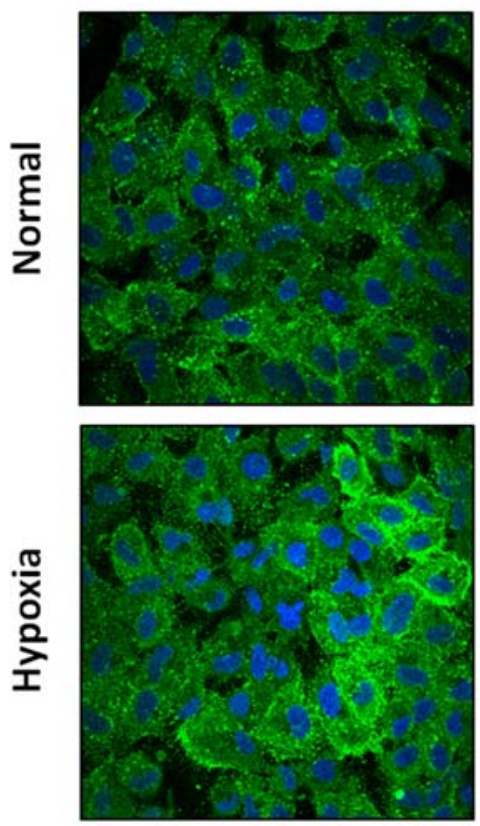

$3 \mathrm{~h}$
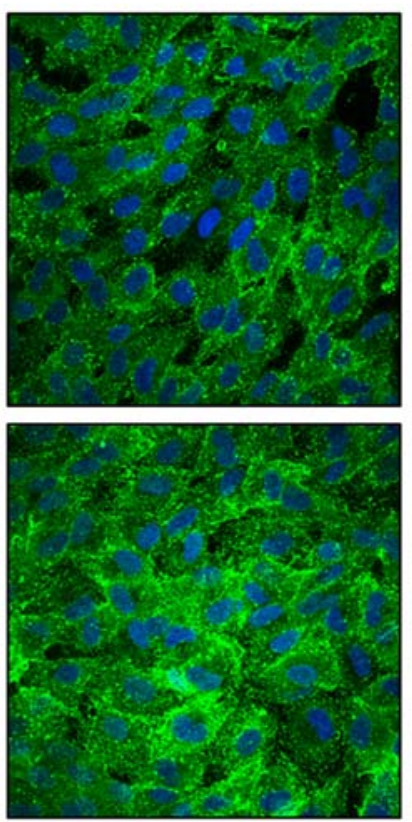

$6 \mathrm{~h}$
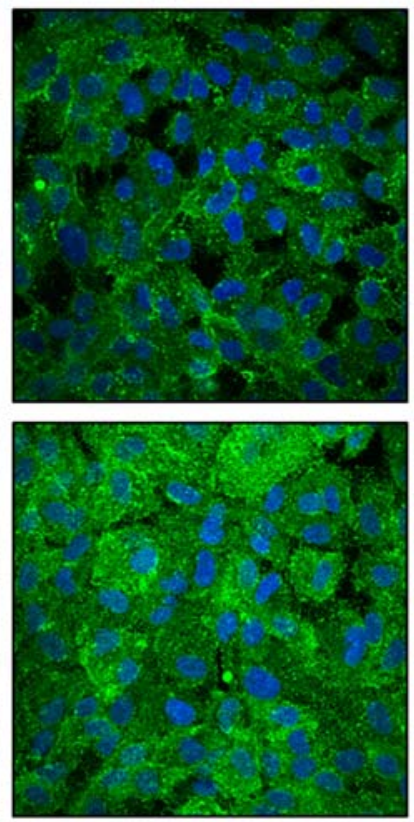

$24 \mathrm{~h}$
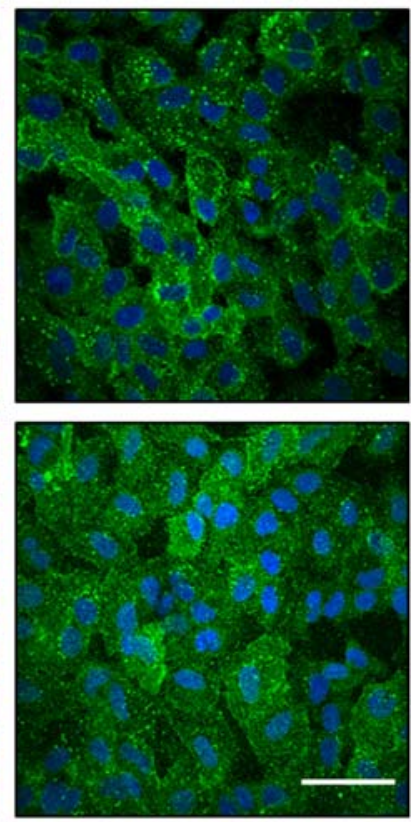

b

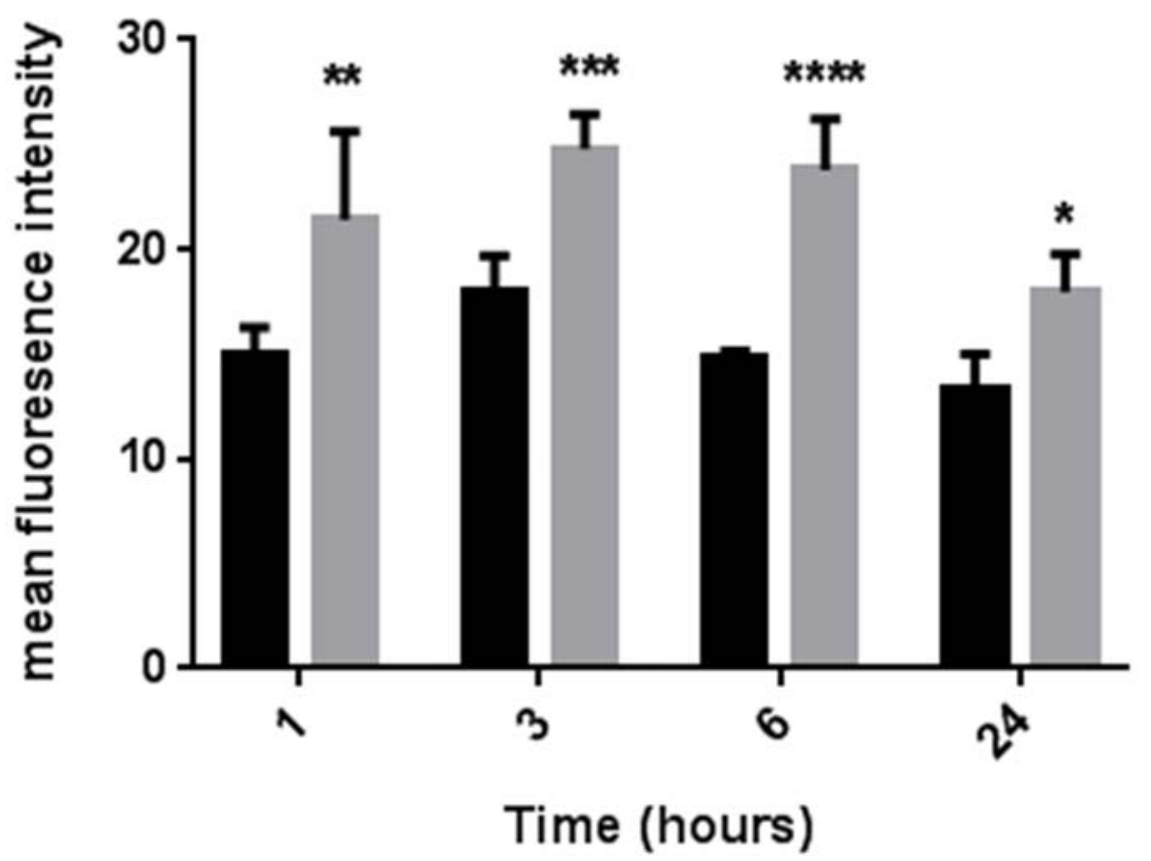

Fig. 4 Syndecan-4 expression in normal vs. hypoxic cells over time. ARPE-19 cells were either exposed to normal culture medium for 1, 3, 6 or $24 \mathrm{~h}$ or treated with HAIR solution to induce hypoxia for $1,3,6$, or $24 \mathrm{~h}$ (a). Syndecan-4 expression (green) was quantified by measuring the mean fluorescence intensity in four areas of each well (b). Two-way

hypoxic cells expressed higher Syndecan-4 levels from 1 to $6 \mathrm{~h}$ compared with normal cultures, with a slight decline at $24 \mathrm{~h}$ likely due to cell death caused by overexposure to HAIR solution, thus reducing the cell density and therefore the overall Syndecan- 4 expression
ANOVA was carried out with post hoc Sidak's test and statistical significance $(* p<0.05, * * p<0.01, * * * p<0.001$, ****p $<0.0001)$ was represented as a difference in expression to normal cells for each time point $(n=4$ mean fluorescence intensity measurements per treatment; mean + SD). Scale bar, $50 \mu \mathrm{m}$

levels. Quantitative analysis revealed that Syndecan-4 expression in hypoxic cells was significantly greater than in normal cells at all time points (Fig. 4b), confirming that ARPE-19 cells increase Syndecan-4 expression in response to hypoxia. 
Previous studies have shown that Syndecan-4 expression increased following acute myocardial infarction in humans, especially in repair regions of damaged cardiac tissue compared with undamaged areas, with hypoxia treatment resulting in increased Syndecan-4 gene expression [65]. This suggests that Syndecan-4 upregulation due to hypoxia during myocardial infarction can act as a repair mechanism due to its cell binding and signalling properties $[56,65]$. Previous studies have also shown that HIF- $1 \alpha$ expression is increased in ARPE-19 cells under hypoxic conditions [7], likely resulting in increased Syndecan- 4 expression. HIF- $1 \alpha$ is a transcription factor for many angiogenic molecules including VEGF, which is overproduced by RPE cells during ischaemia to promote choroidal blood vessel growth and restore the vascular supply $[7,66,67]$. Furthermore, cultured human RPE cells have been shown to have some resistance to hypoxia-mediated cell death in lowered oxygen environments suggesting a functional role under these conditions [68]. It is likely that overexpression during hypoxia occurs to aid angiogenic pathways for retinal homeostasis $[56,69]$. In nAMD, localized sites of ischaemia due to choroidal neovascularization lead to chronic hypoxia in RPE cells stimulating the overproduction of VEGF and perpetuating the disease [1]. Since Syndecan-4 is the target ligand used by XG19 for cellular uptake, increased Syndecan-4 expression in hypoxic RPE cells would allow for targeted delivery to and increased uptake of the peptide into diseased cells [34].

\section{Cell viability post XG19 uptake}

CPP uptake or storage within cells can cause cytotoxicity due to disruption of the cell membrane during uptake or interference with cellular components post uptake [70, 71]. An MTT assay was performed to observe the short- and long-term metabolic activity and cell viability of ARPE-19 cells post XG19 treatment. Cells were exposed to increasing concentrations $(5,10$ or $20 \mu \mathrm{M})$ of XG19 for either 1 or $24 \mathrm{~h}$, with untreated cells serving as a positive viability control. As shown in Fig. 5, XG19-treated cells showed no significant difference in viability when compared with untreated cells at both 1 and $24 \mathrm{~h}$, confirming that the initial uptake process of XG19 did have no effect. Furthermore, even 24-h post uptake of XG19, cell viability was not affected, which is consistent with previous literature showing that Xentry uptake does not affect cell viability $[34,72,73]$.

In addition to cell viability under normal culturing conditions, we investigated whether $\mathrm{Cx} 43 \mathrm{HC}$ block by XG19 during hypoxia can improve cell survival. As shown in Fig. 6, the viability of cells in HAIR solution was significantly reduced compared with cells in normal medium suggesting that hypoxic cells were experiencing injury due to $\mathrm{Cx} 43 \mathrm{HC}$ opening triggering ionic and osmotic imbalances, ATP release and inflammasome activation $[25,74-76]$. It should be noted that the MTT signal does not solely reflect cell viability but may also reflect its metabolic activity [77]. No significant difference in cell viability was seen in XG19-treated hypoxic cells when compared with the untreated cells in normal medium. This confirmed that XG19 prevented a decrease in cell death during hypoxic injury by blocking $\mathrm{Cx} 43 \mathrm{HC}$ opening. The block of ATP release via $\mathrm{Cx} 43 \mathrm{HC}$ inhibition has been shown to reduce retinal injury and promote tissue recovery in rat models of AMD [44, 78]. Therefore, XG19 has great potential to target Syndecan-4 overexpressing cells in nAMD and block Cx43 HC opening and ATP release to promote survival of diseased RPE cells.

\section{EthD-1 uptake}

The ability of XG19 to inhibit HC opening post cellular uptake was observed using the HC-mediated EthD-1 uptake assay. EthD-1 is a small fluorescent molecule which has classically been used as an indicator of dead cells. It enters dead cells via the compromised cell membrane and binds to the nucleus resulting in a bright fluorescence. When the membrane is intact, small molecules such as EthD- 1 can enter cells via open $\mathrm{Cx} 43 \mathrm{HC}$ in a low calcium environment. As such, EthD-1 can be used as an indicator of $\mathrm{HC}$ opening by measuring the fluorescence of EthD1 within intact cells. In addition to native XG19, FITC-labelled XG19 used in the cellular uptake experiments was also tested here to observe if the FITC label itself affects peptide function. Cells exposed to low calcium solution showed increased EthD-1 uptake due to HC opening (Fig. 7a). High calcium solution closed $\mathrm{Cx} 43 \mathrm{HC}$ and therefore inhibited EthD-1 dye uptake. Both XG19 and FITC-XG19 were able to inhibit EthD-1 dye uptake similar to the high calcium control, suggesting that both peptides were available in a biologically active form post cellular uptake. Quantification of mean EthD-1 fluorescence revealed that high calcium $(p<0.0001)$, XG19 and FITC-XG19 $(p<0.001$ for both) resulted in a significant reduction of EthD-1 uptake due to inhibition of $\mathrm{HC}$ opening compared with low calcium solution (Fig. 7b). This confirmed that XG19 functioned as a Cx43 HC blocker and was in a bioavailable form post uptake. Previous experiments observing ethidium bromide uptake into brain slices have shown that up to $172 \mu \mathrm{M}$ of Gap19 had no effect on $\mathrm{Cx} 43$ HC function with inhibition only improved when the concentration was increased to 344-688 $\mu \mathrm{M}$ [32], although this may be partially explained by the additional structural barriers to be overcome by the peptide. Nevertheless, our studies have shown that XG19 concentrations as low as $5 \mu \mathrm{M}$ can block $\mathrm{Cx} 43 \mathrm{HC}$ opening due to the higher uptake efficiency compared with $47 \mu \mathrm{M}$ and $142 \mu \mathrm{M}$ of native peptide needed in C6 (glioma) and astrocyte cultures, respectively $[32,46]$.

\section{ATP release}

XG19 inhibition of HC-mediated ATP release was compared with the known HC and gap junction blocker CBX [24, 79, 


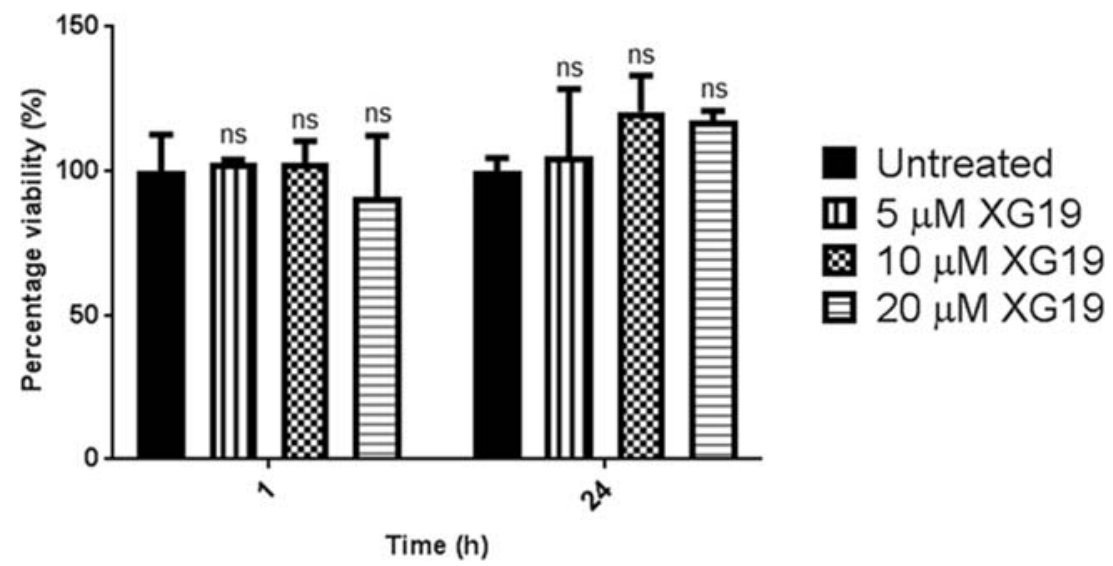

Fig. 5 Cell viability post XG19 uptake under normal conditions. Cell viability of ARPE-19 cells exposed to increasing concentrations of $\mathrm{XG19}(5,10$ or $20 \mu \mathrm{M})$ was assessed at 1 or $24 \mathrm{~h}$ and compared with untreated cells as a control. Statistical analysis was carried out by two-

80]. As shown in Fig. 8, low calcium solution alone resulted in maximal ATP release. Statistical analysis revealed that ATP release was significantly reduced in the presence of XG19 $(p<0.01)$ and CBX $(p<0.0001)$ (Fig. 8a). This confirmed that XG19 was able to block ATP release via HC. The greater reduction in ATP release seen with $\mathrm{CBX}$ compared with $\mathrm{XG19}$ suggests that $\mathrm{CBX}$ is a more efficient $\mathrm{Cx} 43 \mathrm{HC}$ blocker. However, it may also be due to the non-specificity of CBX which blocks multiple channels including other connexin channels as well as pannexins also present in ARPE-19 cells, whereas XG19 is specific to $\mathrm{Cx} 43 \mathrm{HC}$ and thus not interfering

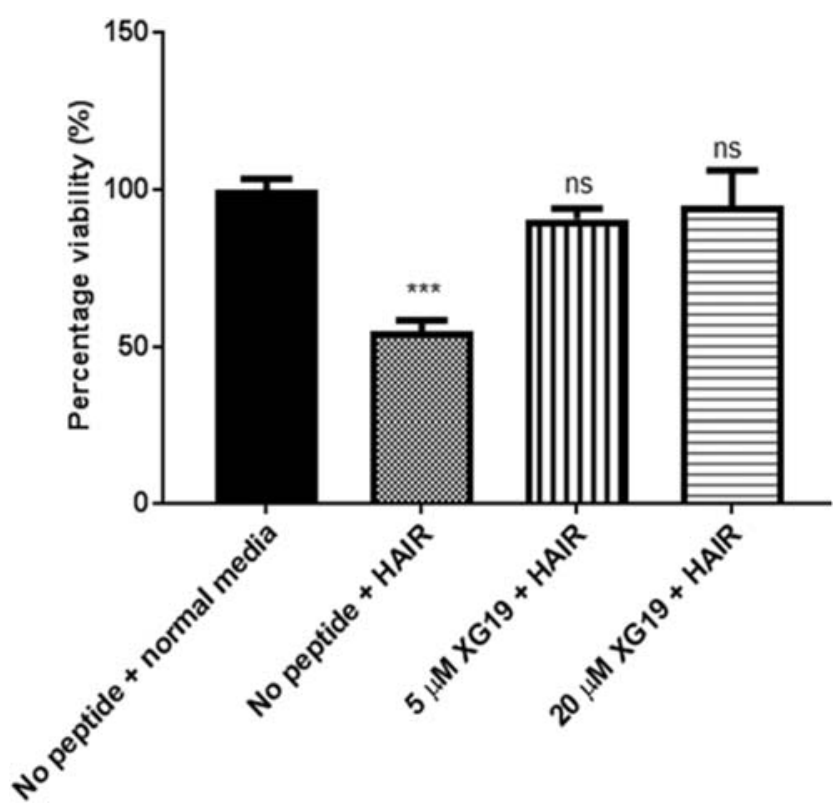

Fig. 6 Cell viability during hypoxia. ARPE-19 cells exposed to HAIR solution to induce hypoxia were treated with either 5 or $20 \mu \mathrm{M}$ of XG19 or were left untreated. Cell viability was assessed using an MTT assay and compared with cells in normal medium. One-way ANOVA was carried out with post hoc Dunnett's test, and statistical significance (ns = not significant, $* * * p<0.001)$ was represented as a difference to untreated cells in normal medium $(n=3$ wells per group; mean $+\mathrm{SD})$

way ANOVA and post hoc Dunnett's multiple comparisons test with statistical significance ( $\mathrm{ns}=$ not significant) represented as a difference from untreated cells ( $n=3$ wells per group; mean $+\mathrm{SD})$

with other ATP releasing channels [24, 79, 80]. Previous studies observing blockage of ATP release with Gap19 have used much higher peptide concentrations $(142 \mu \mathrm{M}$ in astrocytes [32] and $47 \mu \mathrm{M}$ in C6 (glioma) cells [46]) whereas a comparable HC block was achieved with only $5 \mu \mathrm{M}$ of XG19 in the studies presented here, suggesting improved function of XG19 over Gap19 due to improved cell uptake.

Peptide5, an extracellular acting $\mathrm{Cx} 43$ mimetic peptide, has been shown to block the release of ATP via $\mathrm{Cx} 43 \mathrm{HC}[25,36$, 78]. Therefore, XG19 inhibition of ATP release was compared with that of Peptide5 (Fig. 8b). In this assay XG19 was applied at the same time as the low calcium solution to observe if XG19 could act immediately, in a similar way to the extracellular acting Peptide5. As shown in Fig. 8b, ATP release was significantly $(p<0.0001)$ reduced in the presence of both XG19 and Peptide5. This showed that XG19 was able to have a similar onset of action as the well-established extracellular loop Cx43 mimetic peptide, Peptide5. This was an interesting finding as Peptide5 immediately acts on the extracellular region of $\mathrm{Cx} 43$, whereas the efficiency of XG19 depends on its cell uptake in order to interact with the $\mathrm{Cx} 43$ cytoplasmic tail, suggesting that this occurred in a rapid fashion such that intracellular blocking using Xentry as a CPP was as efficient as extracellular blocking [36]. The advantage of XG19 is its ability to maintain gap junction coupling irrespective of dose concentration (discussed in the next section).

To observe if XG19 was still functional several hours post uptake, ATP release was measured 1 and 24-h post uptake. As shown in Fig. 9, XG19 inhibition of Cx43 HC resulted in a significant reduction in ATP release compared with untreated cells at 1 and $24 \mathrm{~h}$. Peptides typically have short half-lives in serum rendering efficient peptide delivery a challenge as the drug must reach its site of action before it is broken down. Therefore, it is interesting to note that XG19 was able to function even 24-h post uptake [81, 82]. Furthermore, Cx43 turnover occurs every few hours depending on the cell type [83], 
Fig. 7 EthD-1 uptake. ARPE-19 cells were treated with low calcium solution alone, high calcium solution, $5 \mu \mathrm{M}$ XG19 or $5 \mu \mathrm{M}$ FITC-XG19 in low calcium solution in the presence of EthD-1 (red), and uptake was observed by a confocal microscope (a). EthD1 uptake was quantified by measuring the mean EthD-1 fluorescence in four areas per treatment group (b). One-way ANOVA was carried out with post hoc Dunnett's test, and statistical significance $(* * * p<0.001$,

$* * * * p<0.0001)$ was represented as a difference from the low calcium control $(n=4$; mean $+\mathrm{SD})$. Scale bar, $500 \mu \mathrm{m}$

a

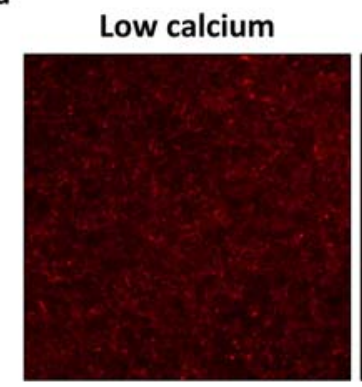

XG19

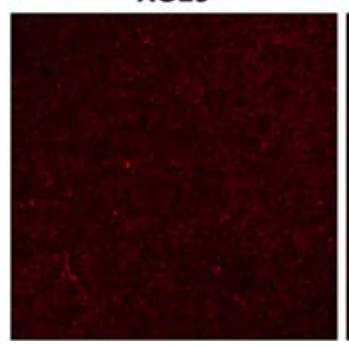

b

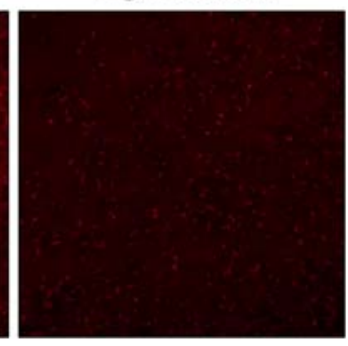

FITC-XG19

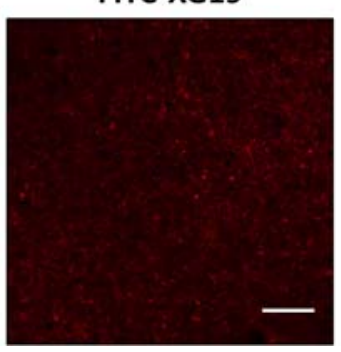

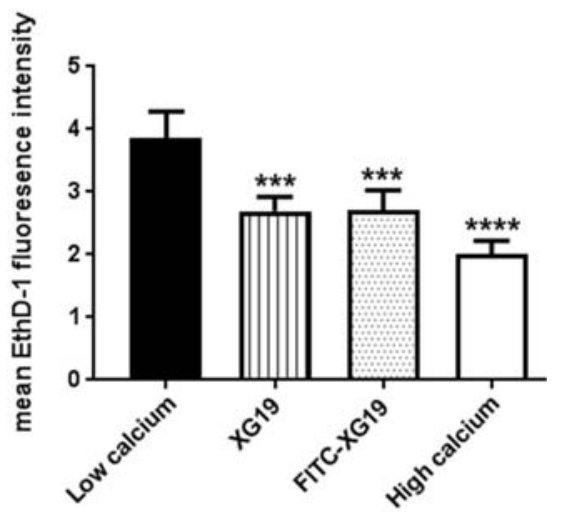

which alters the kinetics of $\mathrm{Cx} 43 \mathrm{HC}$ blockers [84]. This suggested that XG19 was able to block even newly formed $\mathrm{Cx} 43$ $\mathrm{HC}$ at the 24-h time point. Taken together, the rapid cell entry may protect XG19 from degradation and internalized XG19 could potentially act as a reservoir until triggered by a $\mathrm{Cx} 43$ $\mathrm{HC}$ opening event such as hypoxia, thus improving the longterm efficacy of the peptide.

In addition to ATP release under normal culture conditions, we also investigated ATP release during hypoxia. Peptide5, the extracellular loop peptide, has been shown to inhibit ATP release during hypoxia by blocking $\mathrm{Cx} 43 \mathrm{HC}[36,78]$. Therefore, XG19 inhibition of $\mathrm{Cx} 43 \mathrm{HC}-$ mediated ATP release during hypoxic injury was also investigated. As shown in Fig. 10, XG19-treated cells showed a significant reduction

a

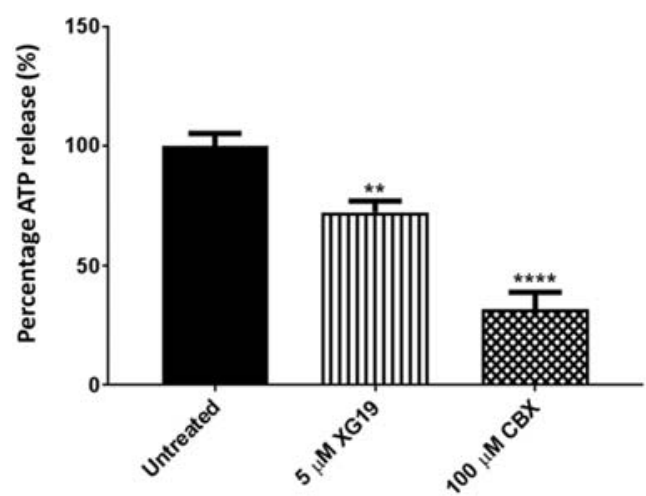

Fig. 8 Inhibition of HC-mediated ATP release with XG19, CBX and Peptide5. ATP release from ARPE-19 cells in low calcium solution either left untreated or pre-treated with $5 \mu \mathrm{M}$ XG19 or $100 \mu \mathrm{M}$ CBX (a). ATP release of ARPE-19 cells in low calcium solution either left untreated or in the presence of $5 \mu \mathrm{M}$ XG19 or $20 \mu \mathrm{M}$ Peptide5 (b). Statistical analysis in ATP release compared with untreated cells in HAIR solution. Furthermore, XG19 was able to efficiently block HC activity at only $5 \mu \mathrm{M}$ with no further decrease in ATP release at higher XG19 concentrations.

\section{Dye scrape-load assay}

Intercellular communication via gap junctions is essential for physiological function with long-term gap junction block detrimental to cell health $[85,86]$. Some extracellularly acting peptides such as Gap27 and Peptide5 may inhibit gap junction function at high concentrations and/or during prolonged periods of exposure [30, 36, 87]. Gap19, however, is said to have no effect on gap junction function $[32,46,88]$. While $\mathrm{Cx} 43 \mathrm{HC}$ are

b

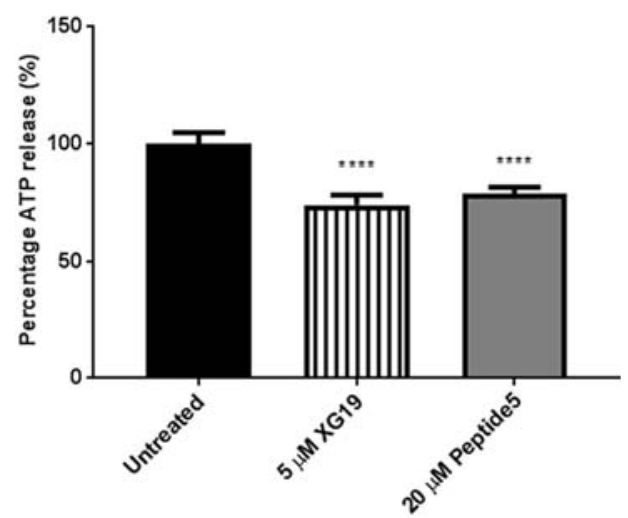

was carried out via one-way ANOVA and post hoc comparisons using Dunnett's test, and statistical significance $(* * p<0.01, * * * * p<0.0001)$ was represented as a difference from untreated cells $(n=3$ wells per group; mean $+\mathrm{SD}$ ) 


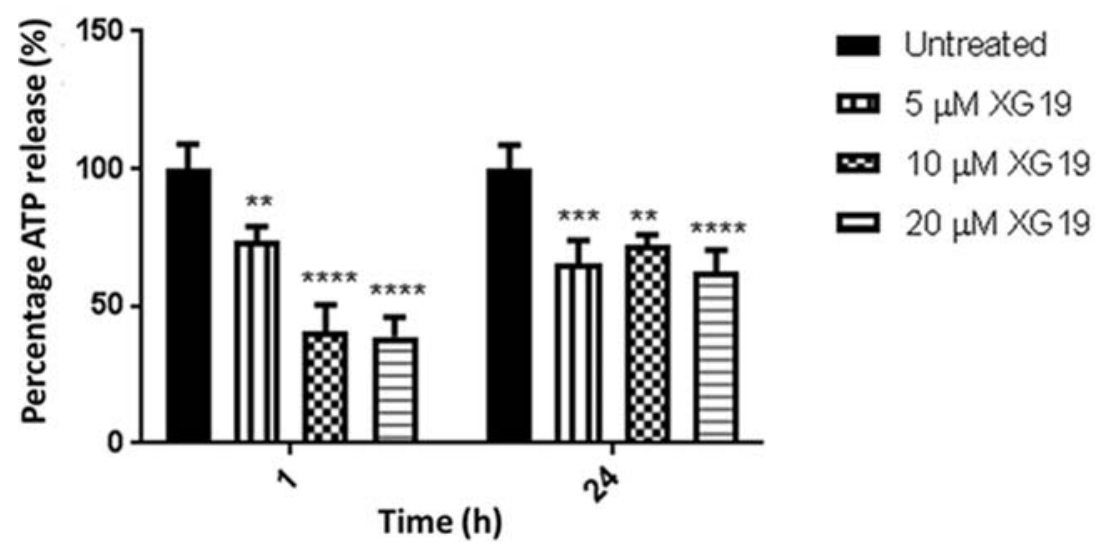

Fig. 9 Inhibition of $\mathrm{Cx} 43 \mathrm{HC}-$ mediated ATP release over time. HC function was assessed via an ATP release assay in ARPE-19 cells either 1 or 24-h post cellular uptake of increasing concentrations of XG19 $(5,10$ or $20 \mu \mathrm{M})$ and compared with untreated cells. Statistical analysis was

closed, the cytoplasmic loop and tail are free and as such gap junctions are open. Therefore, XG19 interference with the cytoplasmic tail inhibits interaction with the cytoplasmic loop and keeps HC closed while gap junctions remain open [32]. The dye scrape/load assay is a classic assay to determine gap junction function [89]. Here, the passage of fluorescent Lucifer Yellow from cell to cell via gap junctions can be visualized [78]. As shown in Fig. 11a, non-scraped cells did not take up any dye whereas when the monolayer was scraped, cells adjacent to the scrape take up Lucifer Yellow and spread into neighbouring cells was allowed via open gap junctions. Consistent with previous literature, cells treated with the non-specific $\mathrm{HC}$ and gap junction

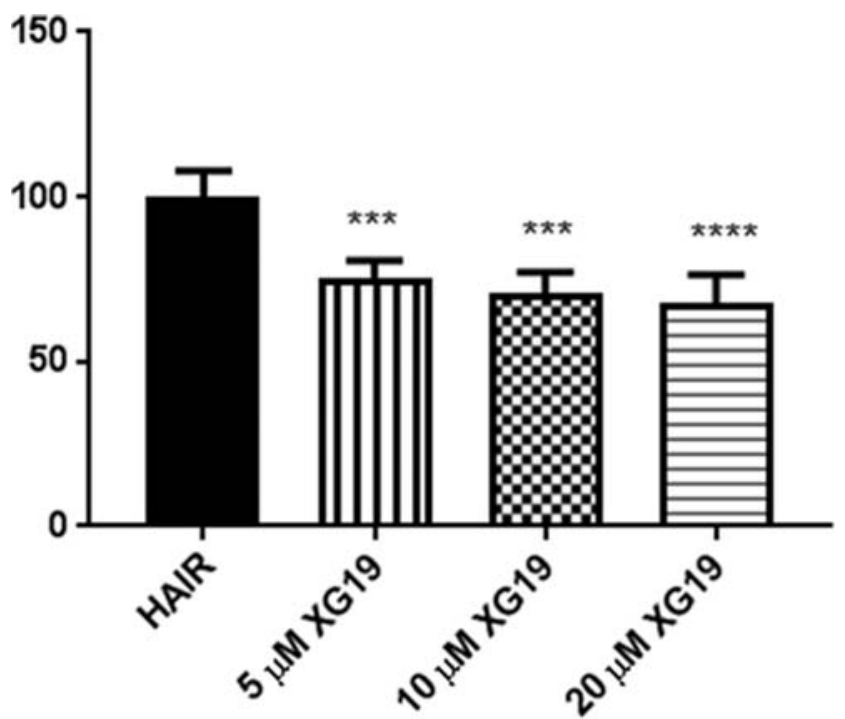

Fig. 10 Inhibition of $\mathrm{Cx} 43 \mathrm{HC}$-mediated ATP release under hypoxic conditions. Cells exposed to HAIR solution to induce hypoxia were treated with 5,10 or $20 \mu \mathrm{M}$ of XG19 or left untreated before assessing HC opening using an ATP assay. One-way ANOVA was carried out with post hoc Dunnett's test, and statistical significance $(* * * p<0.001$, $* * * * p<0.0001)$ was represented as a difference from untreated cells in HAIR solution ( $n=3$ wells per group; mean $+\mathrm{SD})$ carried out by two-way ANOVA and post hoc Sidak's multiple comparisons test. Statistical significance $(* * p<0.01, * * * p<0.001$, $* * * * p<0.0001)$ was in comparison with untreated cells at each time point $(n=3$ wells per group; mean $+\mathrm{SD})$

blocker, CBX, took up Lucifer Yellow into cells immediately adjacent to the scrape, but dye did not further spread to any neighbouring cells due to blocked gap junctions [90]. In addition to Lucifer Yellow uptake at the site of the scrape, XG19-treated cells showed dye transfer to neighbouring cells via gap junctions similar to the untreated control. Lucifer Yellow dye spread was quantified by measuring the total number of pixels in areas that had taken up Lucifer Yellow dye in each of the treatment groups (Fig. 11b). Statistical analysis revealed that the untreated and XG19-treated groups showed significantly higher dye spread than the CBX group $(p<0.01)$. There was no significant difference in the Lucifer Yellow dye spread between the untreated and XG19-treated groups which confirmed that gap junction communication was not affected by XG19. This is consistent with previous studies which have shown the ability of Gap19 to maintain gap junction function post uptake in dye scrape-load assays [32]. Overall, these studies confirmed that while XG19 is a Cx43 $\mathrm{HC}$ blocker, it does not affect gap junction function at the dose level used here.

\section{Conclusion}

These studies showed that XG19 uptake was higher than that of native Gap19 under both normal and hypoxic conditions without any effect on cell viability, suggesting that Xentry is a safe CPP aiding the uptake of Gap19 and providing the potential to reduce administration doses. Previous studies have attempted to improve Gap19 uptake using TAT $[32,33]$. However, TAT raises safety concerns due to its high positive charge and low cell specificity causing cytotoxicity especially in in vivo studies [91-93]. Functional assessments of XG19 post uptake revealed that XG19 was an effective HC blocker without affecting gap junction communication. This suggests that XG19 has the potential to be used for the treatment of 


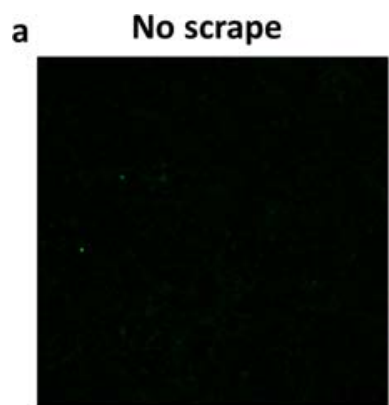

$100 \mu \mathrm{M}$ CBX
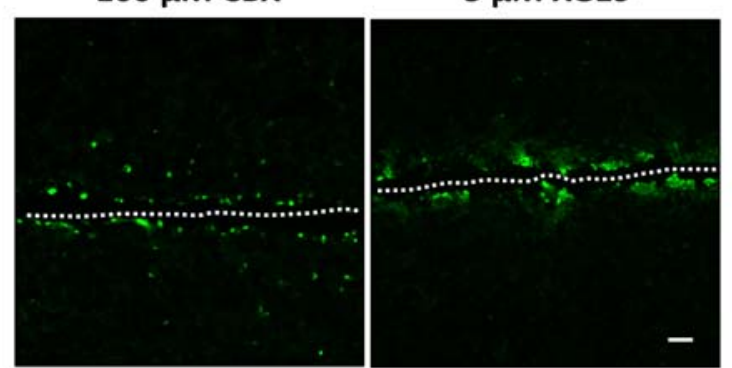

$5 \mu \mathrm{M}$ XG19 b
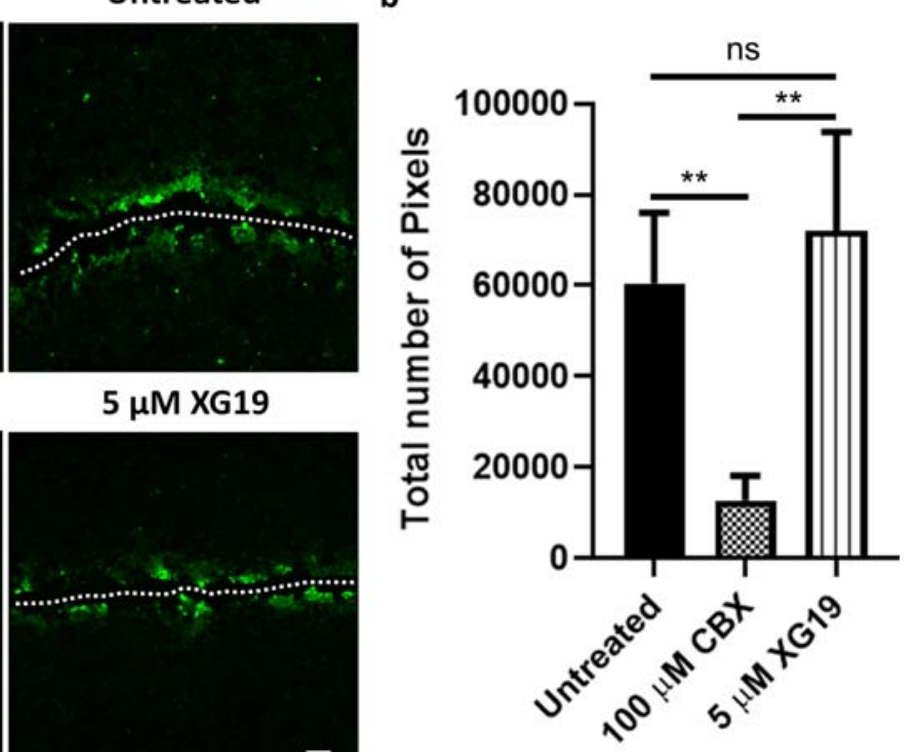

Fig. 11 Dye scrape-load assay. Non-scraped ARPE-19 cells did not take up any Lucifer Yellow dye. Untreated scraped cells (white line) took up dye at the site of injury which was passed onto neighbouring cells via open gap junctions. CBX inhibited gap junction communication, and dye spread to adjacent cells. Dye spread was seen in cells treated with XG19 suggesting functional gap junctions (a). Scale bar, $200 \mu \mathrm{m}$. Dye spread was quantified by measuring the total number of pixels corresponding with Lucifer Yellow dye in each of the treatment groups (b). One-way ANOVA was carried out with post hoc Tukey's multiple comparisons test, and statistical significance $(* * p<0.01$, ns $=$ not significant $)$ was represented as a difference between each of the groups $(n=6$; mean $+\mathrm{SD})$

vein occlusion and stroke where the need to block HC opening upon rapid reperfusion is critical to the survival of the affected and neighbouring tissue. Taken together, XG19 offers a novel approach to targeting hypoxic and inflammatory disease with distinct advantages over existing therapies for many indications.

Funding information F.P.C.'s doctoral studies were supported by a scholarship from the Buchanan Ocular Therapeutics Unit, University of Auckland, New Zealand. This study was partially funded by the Health Research Council of New Zealand [13/692]. C.R.G. holds the W\&B Hadden Chair in Ophthalmology and I.D.R.'s Directorship is supported by the Buchanan Charitable Foundation.

\section{Compliance with ethical standards}

Conflict of interest C.R.G. is a founding scientist of OcuNexus Therapeutics, Inc. (USA) (and previously CoDa Therapeutics, Inc.) which has intellectual property related to the regulation of connexin channels in the treatment of ocular and other disease. F.P.C, C.R.G. and I.D.R. are inventors on a PCT application regarding Xentry fusion peptides for modulation of connexin gap junction and hemichannel activity, with this technology licenced by OcuNexus Therapeutics, Inc. (USA). M.L.A. declares no conflict of interest.

\section{References}

1. McLeod DS, Grebe R, Bhutto I, Merges C, Baba T, Lutty GA. Relationship between RPE and choriocapillaris in age-related 
macular degeneration. Invest Ophthalmol Vis Sci. 2009;50(10): 4982-91.

2. Danesh-Meyer HV, Kerr NM, Zhang J, Eady EK, O'Carroll SJ, Nicholson LF, et al. Connexin43 mimetic peptide reduces vascular leak and retinal ganglion cell death following retinal ischaemia. Brain. 2012;135(Pt 2):506-20.

3. Vadlapatla RK, Vadlapudi AD, Mitra AK. Hypoxia-inducible factor-1 (HIF-1): a potential target for intervention in ocular neovascular diseases. Curr Drug Targets. 2013;14(8):919-35.

4. Grunwald JE, Metelitsina TI, Dupont JC, Ying GS, Maguire MG. Reduced foveolar choroidal blood flow in eyes with increasing AMD severity. Invest Ophthalmol Vis Sci. 2005;46(3):1033-8.

5. Pemp B, Schmetterer L. Ocular blood flow in diabetes and agerelated macular degeneration. Can J Ophthalmol. 2008;43(3): 295-301.

6. Sheridan CM, Pate S, Hiscott P, Wong D, Pattwell DM, Kent D. Expression of hypoxia-inducible factor-1alpha and -2alpha in human choroidal neovascular membranes. Graefes Arch Clin Exp Ophthalmol. 2009;247(10):1361-7.

7. Forooghian F, Razavi R, Timms L. Hypoxia-inducible factor expression in human RPE cells. Br J Ophthalmol. 2007;91(10):140610.

8. Fujita N, Hirose Y, Tran CM, Chiba K, Miyamoto T, Toyama Y, et al. HIF-1-PHD2 axis controls expression of syndecan 4 in nucleus pulposus cells. FASEB J. 2014;28(6):2455-65.

9. la Cour M, Kiilgaard JF, Nissen MH. Age-related macular degeneration: epidemiology and optimal treatment. Drugs Aging. 2002;19(2):101-33.

10. Chappelow AV, Kaiser PK. Neovascular age-related macular degeneration: potential therapies. Drugs. 2008;68(8):1029-36.

11. Veritti D, Sarao V, Lanzetta P. Neovascular age-related macular degeneration. Ophthalmologica. 2012;227(Suppl 1):11-20.

12. Campochiaro PA. Molecular pathogenesis of retinal and choroidal vascular diseases. Prog Retin Eye Res. 2015;49:67-81.

13. Danesh-Meyer HV, Zhang J, Acosta ML, Rupenthal ID, Green CR. Connexin43 in retinal injury and disease. Prog Retin Eye Res. 2016;51:41-68.

14. Mugisho OO, Rupenthal ID, Paquet-Durand F, Acosta ML, Green CR. Targeting connexin hemichannels to control the inflammasome: the correlation between connexin43 and NLRP3 expression in chronic eye disease. Expert Opin Ther Targets. 2019;23(10):855-63.

15. Goodenough DA, Goliger JA, Paul DL. Connexins, connexons, and intercellular communication. Annu Rev Biochem. 1996;65: 475-502.

16. Sohl G, Willecke K. Gap junctions and the connexin protein family. Cardiovasc Res. 2004;62(2):228-32.

17. Beyer EC, Paul DL, Goodenough DA. Connexin43: a protein from rat heart homologous to a gap junction protein from liver. J Cell Biol. 1987:105(6 Pt 1):2621-9.

18. Kumar NM, Gilula NB. The gap junction communication channel. Cell. 1996;84(3):381-8.

19. Kondo RP, Wang SY, John SA, Weiss JN, Goldhaber JI. Metabolic inhibition activates a non-selective current through connexin hemichannels in isolated ventricular myocytes. J Mol Cell Cardiol. 2000;32(10):1859-72.

20. Contreras JE, Sanchez HA, Eugenin EA, Speidel D, Theis M, Willecke K, et al. Metabolic inhibition induces opening of unapposed connexin 43 gap junction hemichannels and reduces gap junctional communication in cortical astrocytes in culture. Proc Natl Acad Sci U S A. 2002;99(1):495-500.

21. Shintani-Ishida K, Uemura K, Yoshida K. Hemichannels in cardiomyocytes open transiently during ischemia and contribute to reperfusion injury following brief ischemia. Am J Physiol Heart Circ Physiol. 2007;293(3):H1714-20.
22. Retamal MA, Froger N, Palacios-Prado N, Ezan P, Saez PJ, Saez JC, et al. Cx43 hemichannels and gap junction channels in astrocytes are regulated oppositely by proinflammatory cytokines released from activated microglia. J Neurosci. 2007;27(50):1378192.

23. Wang J, Ma A, Xi J, Wang Y, Zhao B. Connexin 43 and its hemichannels mediate hypoxia-ischemia-induced cell death in neonatal rats. Child Neurol Open. 2014;1(1):2329048X14544955.

24. Kim Y, Davidson JO, Gunn KC, Phillips AR, Green CR, Gunn AJ. Role of hemichannels in CNS inflammation and the inflammasome pathway. Adv Protein Chem Struct Biol. 2016;104:1-37.

25. Mugisho OO, Green CR, Kho DT, Zhang J, Graham ES, Acosta ML, et al. The inflammasome pathway is amplified and perpetuated in an autocrine manner through connexin 43 hemichannel mediated ATP release. Biochim Biophys Acta. 2018;1862(3):385-93.

26. Mugisho OO, Green CR, Squirrell DM, Bould S, Danesh-Meyer HV, Zhang J, et al. Connexin 43 hemichannel block protects against the development of diabetic retinopathy signs in a mouse model of the disease. J Mol Med (Berl). 2019;97(2):215-29.

27. Leybaert L, Lampe PD, Dhein S, Kwak BR, Ferdinandy P, Beyer $\mathrm{EC}$, et al. Connexins in cardiovascular and neurovascular health and disease: pharmacological implications. Pharmacol Rev. 2017;69(4): 396-478.

28. Evans WH, Boitano S. Connexin mimetic peptides: specific inhibitors of gap-junctional intercellular communication. Biochem Soc Trans. 2001;29(Pt 4):606-12.

29. Boitano S, Evans WH. Connexin mimetic peptides reversibly inhibit $\mathrm{Ca}(2+)$ signaling through gap junctions in airway cells. Am J Phys Lung Cell Mol Phys. 2000;279(4):L623-30.

30. Desplantez T, Verma V, Leybaert L, Evans WH, Weingart R. Gap26, a connexin mimetic peptide, inhibits currents carried by connexin43 hemichannels and gap junction channels. Pharmacol Res. 2012:65(5):546-52.

31. O'Carroll SJ, Alkadhi M, Nicholson LF, Green CR. Connexin 43 mimetic peptides reduce swelling, astrogliosis, and neuronal cell death after spinal cord injury. Cell Commun Adhes. 2008;15(1): $27-42$.

32. Abudara V, Bechberger J, Freitas-Andrade M, De Bock M, Wang $\mathrm{N}$, Bultynck G, et al. The connexin43 mimetic peptide Gap19 inhibits hemichannels without altering gap junctional communication in astrocytes. Front Cell Neurosci. 2014;8:306.

33. Ponsaerts R, De Vuyst E, Retamal M, D'Hondt C, Vermeire D, Wang N, et al. Intramolecular loop/tail interactions are essential for connexin 43-hemichannel activity. FASEB J. 2010;24(11): 4378-95.

34. Montrose K, Yang Y, Sun X, Wiles S, Krissansen GW. Xentry, a new class of cell-penetrating peptide uniquely equipped for delivery of drugs. Sci Rep. 2013;3:1661.

35. Bondarenko A, Chesler M. Rapid astrocyte death induced by transient hypoxia, acidosis, and extracellular ion shifts. Glia. 2001;34(2):134-42.

36. Kim Y, Griffin JM, Harris PW, Chan SH, Nicholson LF, Brimble MA, et al. Characterizing the mode of action of extracellular Connexin 43 channel blocking mimetic peptides in an in vitro ischemia injury model. Biochim Biophys Acta. 2017;1861(2):68-78.

37. Ambati J, Fowler BJ. Mechanisms of age-related macular degeneration. Neuron. 2012;75(1):26-39.

38. Biesemeier A, Taubitz T, Julien S, Yoeruek E, Schraermeyer U. Choriocapillaris breakdown precedes retinal degeneration in agerelated macular degeneration. Neurobiol Aging. 2014;35(11): 2562-73.

39. Ablonczy Z, Dahrouj M, Tang PH, Liu Y, Sambamurti K, Marmorstein $\mathrm{AD}$, et al. Human retinal pigment epithelium cells as functional models for the RPE in vivo. Invest Ophthalmol Vis Sci. 2011;52(12):8614-20. 
40. Dunn KC, Aotaki-Keen AE, Putkey FR, Hjelmeland LM. ARPE19, a human retinal pigment epithelial cell line with differentiated properties. Exp Eye Res. 1996;62(2):155-69.

41. Jonckx B, Porcu M, Candi A, Etienne I, Barbeaux P, Feyen JHM. Assessment of ocriplasmin effects on the citreoretinal compartment in porcine and human model systems. J Ophthalmol. 2017;2017: 2060765.

42. Mugisho OO, Green CR, Zhang J, Binz N, Acosta ML, Rakoczy E et al. Immunohistochemical characterization of connexin 43 expression in a mouse model of diabetic retinopathy and in human donor retinas. Int J Mol Sci. 2017;18(12).

43. Guo CX, Mat Nor MN, Danesh-Meyer HV, Vessey KA, Fletcher EL, O'Carroll SJ, et al. Connexin43 mimetic peptide improves retinal function and reduces inflammation in a light-damaged albino rat model. Invest Ophthalmol Vis Sci. 2016;57(10):3961-73.

44. Mat Nor N, Guo CX, Rupenthal ID, Chen YS, Green CR, Acosta ML. Sustained connexin43 mimetic peptide release from loaded nanoparticles reduces retinal and choroidal photodamage. Invest Ophthalmol Vis Sci. 2018;59(8):3682-93.

45. Chen YS, Green CR, Wang K, Danesh-Meyer HV, Rupenthal ID. Sustained intravitreal delivery of connexin 43 mimetic peptide by poly(D,L-lactide-co-glycolide) acid micro- and nanoparticlesclosing the gap in retinal ischaemia. Eur J Pharm Biopharm. 2015;95(Pt B):378-86.

46. Wang N, De Vuyst E, Ponsaerts R, Boengler K, Palacios-Prado N, Wauman J, et al. Selective inhibition of $\mathrm{Cx} 43$ hemichannels by Gap19 and its impact on myocardial ischemia/reperfusion injury. Basic Res Cardiol. 2013;108(1):309.

47. Chen LJ, Ito S, Kai H, Nagamine K, Nagai N, Nishizawa M, et al. Microfluidic co-cultures of retinal pigment epithelial cells and vascular endothelial cells to investigate choroidal angiogenesis. Sci Rep. 2017;7(1):3538.

48. Vuong TT, Reine TM, Sudworth A, Jenssen TG, Kolset SO. Syndecan- 4 is a major syndecan in primary human endothelial cells in vitro, modulated by inflammatory stimuli and involved in wound healing. J Histochem Cytochem. 2015;63(4):280-92.

49. Baldwin AK, Cain SA, Lennon R, Godwin A, Merry CL, Kielty CM. Epithelial-mesenchymal status influences how cells deposit fibrillin microfibrils. J Cell Sci. 2014;127(Pt 1):158-71.

50. Stewart EA, Samaranayake GJ, Browning AC, Hopkinson A, Amoaku WM. Comparison of choroidal and retinal endothelial cells: characteristics and response to VEGF isoforms and antiVEGF treatments. Exp Eye Res. 2011;93(5):761-6.

51. Pocrnich CE, Shao Q, Liu H, Feng MM, Harasym S, Savage M, et al. The effect of connexin 43 on the level of vascular endothelial growth factor in human retinal pigment epithelial cells. Graefes Arch Clin Exp Ophthalmol. 2012;250(4):515-22.

52. Strauss O. The retinal pigment epithelium. In: Kolb H, Fernandez E, Nelson R, editors. The retinal pigment epithelium. Webvision: the Organization of the Retina and Visual System [Internet]. Salt Lake City (UT): University of Utah Health Sciences Center; 1995.

53. Kolb H. Simple anatomy of the retina. In: Kolb H, Fernandez E, Nelson R, editors. Simple anatomy of the retina. Webvision: the Organization of the Retina and Visual System [Internet]. Salt Lake City (UT): University of Utah Health Sciences Center; 1995.

54. Samuel W, Jaworski C, Postnikova OA, Kutty RK, Duncan T, Tan LX, et al. Appropriately differentiated ARPE-19 cells regain phenotype and gene expression profiles similar to those of native RPE cells. Mol Vis. 2017;23:60-89.

55. Woods A, Couchman JR. Syndecan 4 heparan sulfate proteoglycan is a selectively enriched and widespread focal adhesion component. Mol Biol Cell. 1994;5(2):183-92.

56. Elfenbein A, Simons M. Syndecan-4 signaling at a glance. J Cell Sci. 2013;126(17):3799-804.

57. Baeyens N, Mulligan-Kehoe MJ, Corti F, Simon DD, Ross TD, Rhodes JM, et al. Syndecan 4 is required for endothelial alignment in flow and atheroprotective signaling. Proc Natl Acad Sci U S A. 2014;111(48):17308-13.

58. Le YZ, Bai Y, Zhu M, Zheng L. Temporal requirement of RPEderived VEGF in the development of choroidal vasculature. $J$ Neurochem. 2010;112(6):1584-92.

59. Rousseau B, Larrieu-Lahargue F, Bikfalvi A, Javerzat S. Involvement of fibroblast growth factors in choroidal angiogenesis and retinal vascularization. Exp Eye Res. 2003;77(2):147-56.

60. Qin Y, Zhu Y, Luo F, Chen C, Chen X, Wu M. Killing two birds with one stone: dual blockade of integrin and FGF signaling through targeting syndecan-4 in postoperative capsular opacification. Cell Death Dis. 2017;8(7):e2920.

61. Kauppinen A, Paterno JJ, Blasiak J, Salminen A, Kaarniranta K. Inflammation and its role in age-related macular degeneration. Cell Mol Life Sci. 2016;73(9):1765-86.

62. Ildefonso CJ, Biswal MR, Ahmed CM, Lewin AS. The NLRP3 inflammasome and its role in age-related macular degeneration. Adv Exp Med Biol. 2016;854:59-65.

63. Tanino Y, Chang MY, Wang X, Gill SE, Skerrett S, McGuire JK, et al. Syndecan-4 regulates early neutrophil migration and pulmonary inflammation in response to lipopolysaccharide. Am J Respir Cell Mol Biol. 2012;47(2):196-202.

64. Zhang Y, Pasparakis M, Kollias G, Simons M. Myocyte-dependent regulation of endothelial cell syndecan-4 expression. Role of TNFalpha J Biol Chem. 1999;274(21):14786-90.

65. Kojima T, Takagi A, Maeda M, Segawa T, Shimizu A, Yamamoto $\mathrm{K}$, et al. Plasma levels of syndecan-4 (ryudocan) are elevated in patients with acute myocardial infarction. Thromb Haemost. 2001;85(5):793-9.

66. Maxwell PH, Ratcliffe PJ. Oxygen sensors and angiogenesis. Semin Cell Dev Biol. 2002;13(1):29-37.

67. Ikeda Y, Yonemitsu Y, Onimaru M, Nakano T, Miyazaki M, Kohno $\mathrm{R}$, et al. The regulation of vascular endothelial growth factors (VEGF-A, -C, and -D) expression in the retinal pigment epithelium. Exp Eye Res. 2006;83(5):1031-40.

68. Nash RW, McKay BS, Burke JM. The response of cultured human retinal pigment epithelium to hypoxia: a comparison to other cell types. Invest Ophthalmol Vis Sci. 1994;35(6):2850-6.

69. Tkachenko E, Rhodes JM, Simons M. Syndecans: new kids on the signaling block. Circ Res. 2005;96(5):488-500.

70. El-Andaloussi S, Jarver P, Johansson HJ, Langel U. Cargodependent cytotoxicity and delivery efficacy of cell-penetrating peptides: a comparative study. Biochem J. 2007;407(2):285-92.

71. Maiolo JR, Ferrer M, Ottinger EA. Effects of cargo molecules on the cellular uptake of arginine-rich cell-penetrating peptides. Biochim Biophys Acta. 2005;1712(2):161-72.

72. Montrose K, Yang Y, Krissansen GW. The tetrapeptide core of the carrier peptide Xentry is cell-penetrating: novel activatable forms of Xentry. Sci Rep. 2014;4:4900.

73. Coutinho FP, Green CR, Rupenthal ID. Intracellular oligonucleotide delivery using the cell penetrating peptide Xentry. Sci Rep. 2018;8(1):11256.

74. Saez JC, Green C. Involvement of connexin hemichannels in the inflammatory response of chronic diseases. Int J Mol Sci. 2018;19(9).

75. Saez JC, Schalper KA, Retamal MA, Orellana JA, Shoji KF, Bennett MV. Cell membrane permeabilization via connexin hemichannels in living and dying cells. Exp Cell Res. 2010;316(15): 2377-89.

76. Giaume C, Leybaert L, Naus CC, Saez JC. Connexin and pannexin hemichannels in brain glial cells: properties, pharmacology, and roles. Front Pharmacol. 2013;4:88.

77. Rai Y, Pathak R, Kumari N, Sah DK, Pandey S, Kalra N, et al. Mitochondrial biogenesis and metabolic hyperactivation limits the application of MTT assay in the estimation of radiation induced growth inhibition. Sci Rep. 2018;8(1):1531. 
78. Kim Y, Griffin JM, Nor MNM, Zhang J, Freestone PS, DaneshMeyer HV, et al. Tonabersat prevents inflammatory damage in the central nervous system by blocking connexin 43 hemichannels. Neurotherapeutics. 2017;14(4):1148-65.

79. Udawatte C, Qian H, Mangini NJ, Kennedy BG, Ripps H. Taurine suppresses the spread of cell death in electrically coupled RPE cells. Mol Vis. 2008;14:1940-50.

80. Naus CC, Giaume C. Bridging the gap to therapeutic strategies based on connexin/pannexin biology. J Transl Med. 2016;14(1): 330 .

81. Lau JL, Dunn MK. Therapeutic peptides: historical perspectives, current development trends, and future directions. Bioorg Med Chem. 2018;26(10):2700-7.

82. Mathur D, Prakash S, Anand P, Kaur H, Agrawal P, Mehta A, et al. PEPlife: a repository of the half-life of peptides. Sci Rep. 2016;6: 36617.

83. Laird DW. Life cycle of connexins in health and disease. Biochem J. 2006;394(Pt 3):527-43.

84. Evans WH, Leybaert L. Mimetic peptides as blockers of connexin channel-facilitated intercellular communication. Cell Commun Adhes. 2007;14(6):265-73.

85. Mese G, Richard G, White TW. Gap junctions: basic structure and function. J Invest Dermatol. 2007;127(11):2516-24.

86. Le HT, Sin WC, Lozinsky S, Bechberger J, Vega JL, Guo XQ, et al. Gap junction intercellular communication mediated by connexin 43 in astrocytes is essential for their resistance to oxidative stress. J Biol Chem. 2014;289(3):1345-54.
87. Dhein S. Pharmacology of gap junctions in the cardiovascular system. Cardiovasc Res. 2004;62(2):287-98.

88. Tarzemany R, Jiang G, Jiang JX, Larjava H, Hakkinen L. Connexin 43 hemichannels regulate the expression of wound healingassociated genes in human gingival fibroblasts. Sci Rep. 2017;7(1):14157.

89. el Fouly MH, Trosko JE, Chang CC. Scrape-loading and dye transfer. A rapid and simple technique to study gap junctional intercellular communication. Exp Cell Res. 1987;168(2):422-30.

90. Ke Q, Li L, Cai B, Liu C, Yang Y, Gao Y, et al. Connexin 43 is involved in the generation of human-induced pluripotent stem cells. Hum Mol Genet. 2013;22(11):2221-33.

91. Li W, Bao G, Chen W, Qiang X, Zhu S, Wang S, et al. Connexin 43 hemichannel as a novel mediator of sterile and infectious inflammatory diseases. Sci Rep. 2018;8(1):166.

92. Crespo Yanguas S, da Silva TC, Pereira IVA, Willebrords J, Maes M, Sayuri Nogueira M et al. TAT-Gap19 and carbenoxolone alleviate liver fibrosis in mice. Int J Mol Sci. 2018;19(3).

93. Walrave L, Pierre A, Albertini G, Aourz N, De Bundel D, Van Eeckhaut A, et al. Inhibition of astroglial connexin 43 hemichannels with TAT-Gap19 exerts anticonvulsant effects in rodents. Glia. 2018;66:1788-804.

Publisher's note Springer Nature remains neutral with regard to jurisdictional claims in published maps and institutional affiliations. 